\title{
Co-expression of HIF-1 $\alpha$, MDR1 and LAPTM4B in peripheral blood of solid tumors
}

\author{
Zaira Rehman $^{1}{ }^{\text {, Ammad Fahim }}{ }^{1}$, Attya Bhatti ${ }^{\text {Corresp., }}{ }^{1}$, Hajra Sadia ${ }^{1}$, Peter John ${ }^{1}$ \\ ${ }^{1}$ Atta-ur-Rahman School of Applied Biosciences (ASAB), National University of Sciences and Technology (NUST), Islamabad, Pakistan \\ Corresponding Author: Attya Bhatti \\ Email address: attyabhatti@gmail.com
}

Hypoxic tumor microenvironment is the major contributor of chemotherapy resistance in solid tumors. One of the key regulators of hypoxic responses within the cell is hypoxia inducible factor-1 $\alpha$ that is involved in transcription of genes promoting cell survival and chemotherapy resistance. Multidrug resistance gene-1 (MDR1) and Lysosome-associated protein trans-membrane 4B-35 (LAPTM4B-35) are among those notable players which augment their responses to cellular hypoxia. MDR1 is the hypoxia responsive gene involved in multidrug resistance phenotype while LAPTM4B-35 is involved in chemotherapy resistance by stabilizing HIF-1 $\alpha$ and overexpressing MDR1. Overexpression of HIF-1 $\alpha$, MDR1 and LAPTM4B has been associated with poor disease outcome in many cancers when studied individually at tissue level. However, accessibility of the tissues following the course of chemotherapy for ascertaining chemotherapy resistance is difficult and sometimes not clinically feasible. Therefore, indication of hypoxic biomarkers in patient's blood can significantly alter the clinical outcome. Hence there is a need to identify a blood based marker to understand the disease progression. In the current study the expression of hypoxia associated chemotherapy resistance genes were studied in the peripheral blood lymphocytes of solid tumor patients and any potential correlation with disease progression were explored. The expression of HIF-1 $\alpha$, MDR1 and LAPTM4B was studied in blood of 72 breast, 42 ovarian, 32 colon and 21 prostate cancer patients through real time PCR analysis using delta CT (cycle threshold) method. The statistical scrutiny was executed through Fisher's Exact test and Spearmen Correlation method. There was 12-13 fold increased in expression of HIF-1 $\alpha, 2$ fold increased in MDR 1 and 13-14fold increased in LAPTM4B mRNA level in peripheral blood of breast, ovarian, prostate and colon cancer patients. In the current study there was an association of HIF-1 $\alpha$, MDR1 and LAPTM4B expression with advanced tumor stage, metastasis and chemotherapy treated group in breast, ovarian, prostate and colon cancer patients. The spearmen analysis also revealed a positive linear association among HIF-1 $\alpha$, MDR1 and LAPTM4B in all the studied cancer patients. The elevated expression of HIF-1 $\alpha$, MDR1 and LAPTM4B in peripheral blood of 
solid tumor patients can be a predictor of metastasis, disease progression and treatment response in these cancers. However, larger studies are needed to further strengthen their role as a potential biomarker for cancer prognosis. 
1 Co-expression of HIF-1 $\alpha$, MDR1 and LAPTM4B in Peripheral Blood

2

3 Zaira Rehman, Ammad Fahim, Attya Bhatti*, Hajra Sadia, Peter John

5

6

7

8

9

10

11

12

13

14

15

16

17 Islamabad, Pakistan

*Corresponding Author

Dr. Attya Bhatti

Atta ur Rahman School of Applied Biosciences (ASAB),

National University of Sciences and Technology (NUST),

Sector H-12, Islamabad, Pakistan.

E-mail: attyabhatti@asab.nust.edu.pk

Ph: +92 5190856129

Fax: +92 5190856102

\section{Abstract:}

\section{of Solid Tumors}

Atta-ur-Rahman School of Applied Biosciences (ASAB), National University of Sciences \& Technology (NUST),

Hypoxic tumor microenvironment is the major contributor of chemotherapy resistance in solid tumors. One of the key regulators of hypoxic responses within the cell is hypoxia inducible factor$1 \alpha$ that is involved in transcription of genes promoting cell survival and chemotherapy resistance. Multidrug resistance gene-1 (MDR1) and Lysosome-associated protein trans-membrane 4B-35 (LAPTM4B-35) are among those notable players which augment their responses to cellular hypoxia. MDR1 is the hypoxia responsive gene involved in multidrug resistance phenotype while LAPTM4B-35 is involved in chemotherapy resistance by stabilizing HIF-1 $\alpha$ and overexpressing MDR1. Overexpression of HIF-1 $\alpha$, MDR1 and LAPTM4B has been associated with poor disease outcome in many cancers when studied individually at tissue level. However, accessibility of the tissues following the course of chemotherapy for ascertaining chemotherapy resistance is difficult and sometimes not clinically feasible. Therefore, indication of hypoxic biomarkers in patient's blood can significantly alter the clinical outcome. Hence there is a need to identify a blood based marker to understand the disease progression. In the current study the expression of hypoxia associated chemotherapy resistance genes were studied in the peripheral blood lymphocytes of solid tumor patients and any potential correlation with disease progression were explored. The expression of HIF-1 $\alpha$, MDR1 and LAPTM4B was studied in blood of 72 breast, 42 ovarian, 32 
32 colon and 21 prostate cancer patients through real time PCR analysis using delta CT (cycle threshold) method. The statistical scrutiny was executed through Fisher's Exact test and Spearmen Correlation method. There was 12-13 fold increased in expression of HIF-1 $\alpha, 2$ fold increased in MDR 1 and 13-14 fold increased in LAPTM4B mRNA level in peripheral blood of breast, ovarian, prostate and colon cancer patients. In the current study there was an association of HIF-1 $\alpha$, MDR1 and LAPTM4B expression with advanced tumor stage, metastasis and chemotherapy treated group in breast, ovarian, prostate and colon cancer patients. The spearmen analysis also revealed a positive linear association among HIF-1 $\alpha$, MDR1 and LAPTM4B in all the studied cancer patients. The elevated expression of HIF-1 $\alpha$, MDR1 and LAPTM4B in peripheral blood of solid tumor patients can be a predictor of metastasis, disease progression and treatment response in these cancers. However, larger studies are needed to further strengthen their role as a potential biomarker for cancer prognosis.

\section{Introduction:}

Solid tumors are characteristically known to harbor hypoxic microenvironment which serves as a major impediment to cure by conventional radiotherapy and chemotherapeutic regimens (Brown \& Giaccia 1998; Teicher 1994). In the recent years many targeted therapies have been proposed for cancer treatment but the promiscuous nature of cancer itself makes it difficult to treat by these targeted therapies and still chemotherapy is the main treatment option to cure cancer. Moreover, tumor hypoxia works in synergism with increased drug efflux, thus eventually becoming a daunting task for clinicians to achieve complete cure (Koh \& Powis 2012).

Despite the fact that hypoxia is lethal to both normal as well as tumor cells, cancer cells undergo adaptive and genetic changes for their survival and even proliferation in hypoxic conditions, outpacing their normal counterparts. These changes involve transcription of many genes under the direction of transcription factor- hypoxia inducible factor-1 (HIF-1) (Zimna \& Kurpisz 2015). HIF1 is a dimeric transcription factor that comprises of oxygen dependent HIF-1 $\alpha$ subunit and constitutively expressed HIF-1 $\beta$ subunit. The stabilization of HIF-1 $\alpha$ is done under hypoxic conditions as well as by the action of lysosomal-associated protein transmembrane-4 beta (LAPTM4B) through an unknown mechanism (Meng et al., 2015). HIF-1 $\alpha$ upregulation aids cancerous cells in surmounting the limitations of increased demand of oxygen, glucose and other nutrients by activating HIF inducible genes namely erythropoietin (EPO) (Wang \& Semenza 1993), 
63 vascular endothelial growth factor (VEGF) (Manalo et al. 2005), glycolytic enzymes aldolase A, 64 heme Oxygenase 1, enolase 1, nitric oxide (NO) synthase, lactate dehydrogenase A, phospho-fructo

65

66 kinase 1, carbonic anhydrase (CA-1X), and phosphoglycerate kinase 1 (PGK1) (Benita et al. 2009; Semenza 2012) and genes conferring chemotherapy resistance namely MDR1 (BadowskaKozakiewicz et al. 2017).

Multidrug resistance 1 (MDR1) gene is one of the oldest and well reported gene associated with chemotherapy resistance (Nanayakkara et al. 2018). Increased expression of MDR1 gene in tissue samples of breast, colon, ovarian and gastric cancer patients has been associated with chemotherapy resistance in these cancers (Krishnamachary et al. 2003; Parissenti et al. 1999; Veneroni et al. 1994; Xia et al. 2008; Zhang et al. 2008). Overexpression of MDR1 has been also attributed through overexpression of lysosomal-associated protein transmembrane-4 beta (LAPTM4B) ( $\mathrm{Li}$ et al. 2010). The mechanism of this regulation is explained in the subsequent paragraph.

Lysosomal-associated protein transmembrane-4 beta (LAPTM4B) is an oncogene, initially identified in liver cancer. LAPTM4B associated with mammalian 4-tetratransmembrane spanning protein superfamily, and is largely located on plasma membrane and on membranous organelles such as endosomes and lysosomes (Shao et al. 2003). Hence it is involved in protein trafficking and signal transduction pathways by binding to SH3domain containing proteins (PKC, PP2A, PI3K) through its N-terminal PXXP motif ( $\mathrm{Li}$ et al. 2010). LAPTM4B-35 is having pronounced expression in several solid tumors as HCC (Yang et al. 2010), lung cancer (Tang et al. 2014), colon cancer (Luo et al. 2015), breast cancer (Xiao et al. 2013), prostate (Zhang et al. 2014) and ovarian cancer (Yin et al. 2011). An increased expression of LAPTM4B is found to be affiliated with altered cellular transformation, metastatic cancer progression, and tumorigenesis (Yang et al. 2010; Zhou et al. 2010). Overexpression of LAPTM4B is also accompanied by chemotherapy resistance in cancerous cell lines. The mechanism of this resistance is through the activation of PI3K/AKT pathway which ultimately up-regulate the MDR1 expression in cancer cells ( $\mathrm{Li}$ et al. 2010).

The expression of HIF-1 $\alpha$, MDR1 and LAPTM4B in individual cancers has been well reported and related to cancer progression and metastasis at tissue level however in isolated studies. But the expression of these genes in serum of cancer patients and their potential relation 
93 with clinico-pathological features are scarcely reported. Hence, these finding necessitate 94 investigation regarding whether there will be co-expression of these genes in peripheral blood of solid tumor patients and whether they will be associated with clinicopathological characteristics. The applicability of such investigation may lead to novel approach for studying cancer prognosis utilizing serum rather than actual tissues.

\section{Methodology:}

\section{Blood Sample Collection:}

The study subjects were identified as patients who were having either biopsy proven breast, ovarian, prostate or colon cancer, aging between 25-70, having no other co-morbidity such as diabetes, hypertension, or congenital heart disease. The patients were asked for written informed consent for their potential participation in the study. Ethical approval of the study was obtained from institutional review board of Atta-ur Rahman School of Applied Biosciences NUST (IRB15) and Shifa International Hospital, Islamabad (shifa-ref-183-2015).

Blood samples ( $5 \mathrm{~mL}$ ) from 72 breast, 42 ovarian, 21 prostate, and 32 colon cancer patients were collected. The samples were collected in HTS sterile vacuum collection tubes and immediately put on ice to avoid RNA degradation. The clinical characteristics of patients including stage and metastasis were obtained from pathological reports (Table 1). The staging was defined using the American Joint Committee on Cancer (AJCC) classification system. Patients were classified into two classes on the basis of their age (less than 50 and above 50). The patients were also segregated into two groups on the basis of tumor stage; low stage group (I-II) and higher stage group (III-IV). For the purpose of analysis, the patients were classified into chemotherapy naïve (no prior chemotherapy exposure) and chemotherapy administered group (five cycles completed). Patients who were selected for chemotherapy administered group were given standard chemotherapy treatment for breast cancer (ABVD (Adriamycin (doxorubicin), Bleomycin, Vinblastine, Dacarbazine) or CEF (cyclophosphamide, epirubicin, fluorouracil), ovarian cancer (Paclitaxel, carboplatin or Docetaxel, carboplatin), prostate cancer (Docetaxel prednisone or Mitoxantrone (Novantrone) and prednisone) and colon cancer (leucovorin, dexamethasone, secouracil, Oxaliplatin). For controls, the blood samples from 60 females and 30 males with age ranging between 25-60 years, were collected with no documented co-morbidity. 
122

123

124

125

126

127

128

129

130

131

132

133

134

135

136

137

138

139

140

141

142

143

144

145

146

147

148

149

\section{RNA Extraction and cDNA Synthesis:}

Extraction of total RNA from whole blood was conducted using TriZol reagent (Thermo Fischer Scientific). All the reactions were performed on ice in order to avoid degradation. The concentration and purity of RNA was determined through NanoDrop 2000 (Thermo Fischer Scientific) and the samples with ratio A260/A280 > 1.6 were used for cDNA synthesis. For cDNA synthesis $20 \mu \mathrm{L}$ of reaction volume was prepared by adding 100ng of RNA, $1.5 \mathrm{mM}$ dNTPs, 100 $\mu \mathrm{M}$ oilgodT, $200 \mathrm{U}$ reverse transcriptase, $10 \mathrm{U}$ RNase inhibitor and DEPC water up-to $20 \mu \mathrm{L}$. The reverse transcription reaction was started at $42^{\circ} \mathrm{C}$ for $60 \mathrm{~min}$ and terminated at $70^{\circ} \mathrm{C}$ for $10 \mathrm{~min}$. The cDNA was then stored at $-20^{\circ} \mathrm{C}$.

\section{Expression Analysis of HIF-1 $\alpha$, MDR1, and LAPTM4B:}

The Expression analysis of HIF-1 $\alpha$, MDR1 and LAPTM4B genes was carried out using real time PCR analysis. Primers used for expression analysis of HIF-1 $\alpha$ forward 5'CGCATCTTGATAAGGCCTCT-3', Reverse 5'- TACCTTCCATGTTGCAGACT-3', MDR1 forward 5'- AACGGAAGCCAGAACATTCC-3', Reverse 5'AGGCTTCCTGTGGCAAAGAG-3', LAPTM4B forward 5'- CCTCACTGCCAGATC-3', reverse 5'- CTATCTGTGGCATACCT-3' and GAPDH (internal control) forward 5'CCCCTTCATTGACCTCAACTACA-3', reverse 5'- CGCTCCTGGAGGATGGTGAT-3'. No template/negative controls (NTC) was included for all the primers in each run. The reaction mixture comprised of $200 \mathrm{ng}$ of template cDNA, $0.5 \mu \mathrm{M}$ of each forward and reverses primer, 12.5 $\mu \mathrm{L}$ of SYBER Green master mix and nuclease free water to make up $20 \mu \mathrm{L}$ of final volume. The thermal cycler conditions were as follows; initial denaturation at $95{ }^{\circ} \mathrm{C}$ for $10 \mathrm{~min}$, followed by 40 cycles of denaturation at $95{ }^{\circ} \mathrm{C}$ for $30 \mathrm{sec}$, annealing at $60{ }^{\circ} \mathrm{C}$ for $60 \mathrm{sec}$ and extension at $72{ }^{\circ} \mathrm{C}$ for $45 \mathrm{sec}$. All the experiments were run in triplicates and their average was accounted for analysis. Data was analyzed using comparative cycle threshold method $(\Delta \mathrm{Ct})$ and were normalized according to GAPDH expression in each sample.

\section{Statistical Analysis:}

Statistical inquiry was performed using Statistical software package SPSS 21. The Fisher's Exact test was used to show the relationship between different clinicopathological variables and 
150 expression of HIF-1 $\alpha$, MDR1 and LAPTM4B. Spearmen correlation was performed to find the

151 association between HIF-1 $\alpha$, MDR1, and LAPTM4B. The significance is defined as $\mathrm{p}<0.05$.

152 Results:

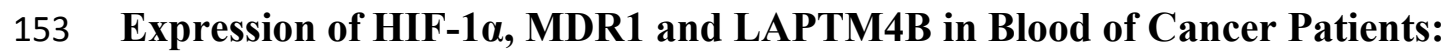

154 There was a high expression of HIF-1 $\alpha$ observed in peripheral blood of breast $(2.389 \pm$ $1550.1597)$, ovarian $(2.647 \pm 0.1541)$, prostate $(2.689 \pm 0.2272)$ and colon $(2.369 \pm 0.1810)$ cancer 156 patients as compared to healthy controls $(0.1806 \pm 0.1236)$. In general, there was 12-13fold 157 increase in expression of HIF-1 $\alpha$ in all the studied cancer patients. There was also an elevated 158 expression of MDR1 observed in the blood of breast $(2.717 \pm 0.1145)$, ovarian $(2.498 \pm 0.1191)$, 159 prostate $(2.391 \pm 0.2224)$ and colon $(2.634 \pm 0.1782)$ cancer patients compared to healthy controls 160 (1.245 \pm 0.08544$)$ (Fig. 1). Hence there was almost 2-fold increase in expression of MDR1 in 161 cancer patients as compared to healthy controls. The high level of LAPTM4B expression was 162 observed in the breast $(2.703 \pm 0.1312)$, ovarian $(2.849 \pm 0.1501)$, prostate $(2.567 \pm 0.1786)$ and 163 colon $(2.688 \pm 0.1949)$ cancer patients compared to healthy controls $(0.2546 \pm 0.09648)$ (Fig. 1). 164 In case of LAPTM4B, there was 13-14fold increase in expression of LAPTM4B in all the cancer 165 samples compared to normal healthy controls.

166 Correlation of HIF-1a, MDR1 and LPATM4B Expression with Clinical Features in Breast 167 Cancer:

168 The summarized statistics of HIF-1 $\alpha$, MDR1 and LAPTM4B expression as well as their 169 clinico-pathological features is shown in Table 2. HIF-1 $\alpha$, MDR1 and LAPTM4B expression did not have any correlation with age of patients $(\mathrm{p}>0.05)$. Instead, they showed an association with tumor stage and metastasis $(\mathrm{p}<0.05)$. In advanced stage group, there were $>80 \%$ of patients with higher expression of all the three genes. While in lower stage group the high expression of HIF1 $\alpha$, MDR1 and LAPTM4B was found in 31\%, 37\%, and 56\% of patients, respectively. Similar scenario was observed in metastatic and non-metastatic group where in metastatic group, $>80 \%$ of patients with elevated expression while in non-metastatic group $38 \%, 71 \%$, and $66 \%$ of patients were having elevated expression of HIF-1 $\alpha$, MDR1 and LAPTM4B, respectively. It was also observed that have increased expression in patients who underwent the chemotherapy treatment at the time of sample collection as compared to treatment naïve group (Fig. 2). 80\%, 82\% and 77\%

179 of patients in the pre-treated group are having elevated expression of HIF-1 $\alpha$, MDR1 and 
180 LAPTM4B, respectively. In treatment naïve group, 53\%, 33\%, and $60 \%$ of patients were having 181 high expression of HIF-1 $\alpha$, MDR1 and LAPTM4B, respectively.

182 Correlation of HIF-1 $\alpha$, MDR1 and LPATM4B Expression with Clinical Features in Ovarian 183 Cancer:

184 The correlation of HIF-1 $\alpha$, MDR1 and LAPTM4B expression with clinical features of 185 ovarian cancer patients is shown in Table 3. No correlation of HIF-1 $\alpha$, MDR1 and LAPTM4B 186 expression was associated with age of patients in ovarian cancer $(\mathrm{p}>0.05)$. Increased expression 187 of HIF-1 $\alpha$, MDR1 and LAPTM4B was observed with higher tumor stage and distant metastasis $188(\mathrm{p}<0.05)$. Among advanced stage group, 80\% of patients were presenting high expression while 189 in lower stage group 40-60\% of patients were exhibiting high expression of three genes. In non190 metastatic group, 60\% of patients with high expression of three genes while among metastatic 191 group, 85\%, 67\%, and 75\% of patients were having elevated expression of HIF-1 $\alpha$, MDR1 and 192 LAPTM4B, respectively. We observed an elevated expression of these genes in pre-treated group 193 (p<0.05) (Fig. 3). In pre-treated group 70-85\% of patients while in treatment naïve group, 25-37\% 194 of patients were having elevated expression of all the three genes.

195 Correlation of HIF-1 $\alpha$, MDR1 and LAPTM4B Expression with Clinical Features in Prostate 196 Cancer:

197 The relationship of different clinical parameters of prostate cancer with HIF-1 $\alpha$, MDR 1 and 198 LAPTM4B expression is shown in Table 4 (Fig. 4). In case of prostate cancer all the patients were 199 above age 50 and no patients were below 50 hence we did not find any correlation of age with 200 expression of HIF-1 $\alpha$, MDR1, and LAPTM4B. HIF-1 $\alpha$ and LAPTM4B expression was correlated 201 with tumor stage $(\mathrm{p}<0.05) .50 \%$ of patients in lower stage group while $66 \%$ and $80 \%$ of patients 202 in the advanced stage group exhibiting high expression of HIF-1 $\alpha$ and LAPTM4B, respectively. 203 Among metastatic and localized disease group, high expression of HIF-1 $\alpha$ and LAPTM4B was 204 observed in patients with distant metastasis $(\mathrm{p}<0.05)$. As there were $69 \%$ and $76 \%$ of patients 205 among metastatic group were having high expression of HIF-1 $\alpha$ and LAPTM4B, respectively. No 206 correlation of MDR1 expression was observed with tumor stage and metastasis $(\mathrm{P}>0.05)$. High 207 expression of HIF-1 $\alpha$ and MDR1 expression was observed in the patients who were under the 208 chemotherapy treatment $(\mathrm{p}<0.05)$. In treatment naïve group $42 \%$ of patients while in pre-treated 209 group, $71 \%$ and $64 \%$ of patients were having elevated expression of HIF-1 $\alpha$ and LAPTM4B, 210 respectively. 
212 Correlation of HIF-1a, MDR1 and LAPTM4B Expression with Clinical Features in Colon 213 Cancer:

214 In colon cancer, high expression of HIF-1 $\alpha$, MDR1 and LAPTM4B was correlated to 215 clinical features of patients (Table 5; Fig. 5). The elevated expression of HIF-1 $\alpha$, MDR1 and 216 LAPTM4B was found to be correlated with advanced tumor stage and metastasis $(\mathrm{p}<0.05)$. In 217 advanced tumor stage, $84 \%$ and $57 \%$ of patients while in lower stage group $30 \%$ and $46 \%$ of 218 patients were having elevated expression of HIF-1 $\alpha$, MDR1 and LAPTM4B. There was elevated 219 expression of all the three genes was observed in metastatic group compared to patients with non220 metastatic disease as there was $85 \%, 62 \%$, and $52 \%$ of patients in the metastatic group were 221 exhibiting high expression of HIF-1 $\alpha$, MDR1 and LAPTM4B, respectively. The elevated 222 expression was also observed in patients who were under the chemotherapy treatment at the time 223 of sample collection $(\mathrm{p}<0.05) .78 \%, 68 \%$, and $58 \%$ of patients in the pre-treated group were 224 showing elevated expression of HIF-1 $\alpha$, MDR1 and LAPTM4B, respectively.

\section{Association between HIF-1 $\alpha$, MDR1 and LAPTM4B Expression in Solid Tumors}

The spearmen analysis revealed a linear positive correlation between HIF-1 $\alpha$ and MDR1 expression $(\mathrm{p}<0.001 ; \mathrm{R} \geq 0.8)$ in the blood of breast (Table 6), ovarian (Table 7), prostate (Table 8) and colon cancer (Table 9). In case of breast cancer, there were 51 patients that were having high expression of HIF-1 $\alpha$, MDR1 and LAPTM4B while 17 patients were those having low expression of all the three genes. Hence, a positive linear correlation was found between these genes with $R$ $=0.900$ and $P<0.001$. In case of ovarian cancer 27 patients were those having high expression of HIF-1 $\alpha$, MDR 1 and LAPTM4B while 10 patients were those having low expression of all the three genes, which showed a positive linear correlation among these genes $(R=0.849, P<0.001)$. similar pattern of linear correlation was also found among HIF-1 $\alpha$, MDR1, and LAPTM4B in case of prostate cancer $(R=0.806, P<0.001)$ with 12 patients having high expression of these genes while 6 patients having low expression of these genes. In case of colon cancer 12 patients were those having high expression of HIF-1 $\alpha$ and MDR1 while 15 were those with high expression of LAPTM4B also harboring high expression of MDR1 and HIF-1 $\alpha$. Hence a positive linear correlation was observed with $R=0.825$ and $P<0.001$. The positive correlation among all the studied cancers suggest similar upregulation of LAPTM4B leading to increased HIF-1 $\alpha$ and MDR1 genes. 


\section{Discussion:}

243 Chemotherapy is one of the frontline options in administering curative or palliative care.

244 However, drug resistant cancer phenotypes are major impediment in achieving clinical therapeutic 245 goals. There have been practical limitations which have impacted the research on identification of 246 chemotherapy resistance markers. Generally, patients are managed by chemotherapeutic 247 management after the combination of histological and radiological evaluation made at the time of 248 diagnostic workup. However, as the chemotherapeutic treatment progresses, the ensuing therapy 249 resistance processes owing to intra and inter tumoral heterogeneity may blur the prognostic 250 outcome to negativity. Moreover, the same heterogeneity of treatment resistant sub clonal 251 population of cancer cells, widespread metastasis and clinical complications embedded with 252 invasive procedures decrease the feasibility of clinical reassessment by tissue re-biopsy (Bedard 253 et al. 2013; Gerlinger et al. 2012; Jiang et al. 2016; Sholl et al. 2016).

254 Chemotherapy resistance has been reported in conjunction with at-least three cell 255 membrane pumps known to actively drive out chemotherapy drugs from the interior i.e MDR1, 256 MRP1 and BCRP (Gottesman et al. 2002; Schinkel et al. 1994; Szakacs et al. 2004). The hyper 257 proliferative tumor state alters biological characteristics of the tissue microenvironment inducing 258 tumor hypoxia. This hypoxia in turn, is one of the most important drivers of tumor aggressiveness. 259 Normally the partial oxygen pressure $\left(\mathrm{pO}_{2}\right)$ is ranging between $40-65 \mathrm{~mm} \mathrm{Hg}$, however to drop 260 to $10 \mathrm{~mm}$ of $\mathrm{Hg}$ or less is in 60\% of the solid tumors (Zimna \& Kurpisz 2015). This hypoxia 261 triggers HIF-1 $\alpha$, which is known to be a detrimental factor in further modifying tumor 262 microenvironment towards drug resistance and aberrant tissue invasion. HIF-1 $\alpha$ is degraded under normoxia while it stabilizes under hypoxic conditions. There are additional players contributing to HIF-1 $\alpha$ overexpression constituting tumor suppressor genes inactivation or oncogene activation. Furthermore, v-Src, insulin, insulin-like growth factor (IGF)-1 or IGF-2, pyruvate, and lactate also magnifies the HIF-1 $\alpha$ expression (Benita et al. 2009; Semenza 2012). The ensuing hypoxia also upregulates genes operational in lysosomal pathway which includes LAPTM4B, a novel oncogene initially identified in hepatocellular carcinoma but having important role in hypoxia induced autophagy and mitophagy (Lai et al. 2016). Previous literature suggests that LAPTM4B aids cancer cells towards survival advantage by promoting resistance to hypoxic microenvironment, nutrient deprivation and genotoxic stress contemplated by chemotherapy (Dielschneider et al. 272 2017). 
274 different cancers at tissue levels and provide a directional evidence regarding the engagement of

275 these genes in tumor expansion, metastasis and therapy resistance(Gottesman et al. 2002; Gruber 276 et al. 2004; Holzmayer et al. 1992; Li et al. 2010).

277

278

279

280

281

282

283

284

285

286

287

288

289

290

291

292

293

294

295

296

297

298

299

300

301

302

The data regarding the co-expression of these genes in peripheral blood is not available. Hence, this study was aimed to measure the co-expression of HIF-1 $\alpha$, MDR1 and LAPTM4B genes in blood of breast, ovarian, prostate and colon cancer patients and matched with appropriate controls. To the best of our knowledge, it is the first study to put forward preliminary evidence regarding the co-expression of these genes in the blood of different solid tumors, while also finding their correlation with cancer progression.

The appearance of HIF-1 $\alpha$ in peripheral blood may be implicated to come from PBMCs. HIF-1 $\alpha$ expression from TILs (Tumor Infiltrating Lymphocytes), TAMs (Tumor Associated Macrophages) has been studied for its potential role in cancer progression and metastasis (Wigerup et al. 2016). However, there has been reported evidence of circulating tumor cells (CTCs) to be another contributing factor of HIF-1, MDR1 and LAPTM4B in patient's blood (Kallergi et al. 2009; Liu et al. 2003; Robey et al. 2006). Moreover, the CTCs has also been reported to be utilized as a repeatable biomarker for monitoring tumor response (Jakabova et al. 2017). Serum concentrations of HIF-1 $\alpha$ have been studies elsewhere in Graves' disease (Liu et al. 2018) as well as in case of prostate cancer (Pipinikas et al. 2008). The presence of HIF-1 $\alpha$ can be traced back to HIF stabilization which is driven by accumulation of TCA intermediates succinate and fumarate (Hewitson et al. 2007; Koivunen et al. 2007). This has been the case along with alteration in genes encoding TCA intermediates in various solid tumors (LaGory \& Giaccia 2016; Lee et al. 2016; Pollard et al. 2005). With reference to LAPTM4B, it has been extensively studied for genotyping studies associated with various cancers from serum as well as investigated for its expression in PBMCs and platelets(Cheng et al. 2016; Gnatenko et al. 2010; Huygens et al. 2015; Ma et al. 2015; Mo et al. 2014).

The current study confirmed the elevated expression of HIF-1 $\alpha$ in peripheral blood of solid tumor patients as compared to normal healthy controls that have very low or negligible expression of HIF-1 $\alpha$. The stabilization of HIF-1 $\alpha$ leads to the overexpression of hypoxia responsive genesthe MDR1. The present study also confirmed the overexpression of MDR1 in the blood of solid 
303 tumor patients as compared to healthy controls. We have also found an elevated expression of

304 LAPTM4B in blood of these patients compared to healthy controls. The results are comparable to 305 previously published data, about the expression of HIF-1 $\alpha$, MDR1 and LAPTM4B studied

306

307

308

309

310

311

312

313

314

315

316

317

318

319

320

321

322

323

324

325

326

327

328

329

330

331

332

333 separately in solid tumor tissue samples. The elevated HIF-1 $\alpha$ expression has been reported in many cancers including breast, liver, colon, ovarian, brain, prostate, bladder, lung and renal cancer (Mansour et al. 2016; Talks et al. 2000; Zhong et al. 1999). High expression of MDR1 has been reported in ovarian ( $\mathrm{Lu}$ et al. 2007), breast ( $\mathrm{Lu}$ et al. 2012), non-small cell lung cancer (Holzmayer et al. 1992) and prostate cancer (Bhangal et al. 2000). Immunohistochemistry analysis also proved up-regulation of LAPTM4B-35 protein in a wide range of solid tumors (Luo et al. 2015; Tang et al. 2014; Zhang et al. 2014). Previously, the overexpression of LAPTM4B has been studied in serum of breast cancer patients compared to healthy controls (Shaker et al. 2015).

Previous findings from the reported literature as well as findings from our study, direct towards potentially substantial evidence of related elevated expression of HIF-1 $\alpha$, MDR1 and LAPTM4B as an indicator of tumor progression, higher tumor stage and resistance to chemotherapy in breast, ovarian, colon and prostate cancer. The mechanism behind the involvement of HIF-1 $\alpha$ in metastasis, tumor progression and chemotherapy resistance is due to the resultant overexpression of VEGF and MDR1. Both of these genes are hypoxia responsive genes (Yang et al. 2016). Moreover, LAPTM4B under hypoxic cellular adaptation, chip in a compelling part towards cell proliferation furthering tumor expansion rather than simply being upregulated as a secondary outcome of speedy tumorigenesis. The overexpression of LAPTM4B positively regulates autophagy and enhancing mitochondrial clearance thus preventing ROS accumulation resultantly inhibiting apoptosis (Lai et al. 2016). Moreover, the elevated expression of LAPTM4B decreases lysosomal-mediated cell death (LCD) by interfering with ceramide sequestration, hence stabilizing endosomes (Saksena et al. 2009). Finally, LAPTM4B is known to mediate chemotherapy resistance enhancing efflux transporters (MDR1) expression. (Futter et al. 2001).

The current study provides an evidence of close association of HIF-1 $\alpha$, MDR1 and LAPTM4B expression with tumor stage, metastasis and chemotherapy treatment in breast cancer patients. Previously it has been suggested that elevated HIF-1 $\alpha$ expression in breast cancer tissue is an indicator of metastasis and relapse in breast cancer (Bos et al. 2003; Generali et al. 2006; Gruber et al. 2004). By doing immunohistochemistry of 740 breast cancer patients Dales et al., found HIF-1 $\alpha$ significantly correlated with metastasis and it also correlated with higher local 
334 recurrence (Dales et al. 2005). Gruber et al., found the positive association of HIF-1 $\alpha$ with tumor

335 stage in breast cancer patients (Gruber et al. 2004; Lu et al. 2012). Lu and colleagues identified a 336 significant correlation of MDR1 expression with metastasis as compared to primary tumors (Lu et 337 al. 2012). Burger et al., studied the mRNA levels in primary breast cancer patients and found that 338 MDR1 is an important determinant of clinical outcome in patients who have been tried 339 chemotherapy as a first line treatment option (Burger et al. 2003). In the current study the patients 340 had received the ABVD or CEF chemotherapy regimen. In ABVD regimen doxorubicin and 341 vinblastine while in $\mathrm{CEF}$ regimen epirubicin are the substrates of MDR1. Hence the patients 342 having these regimens showed an increased level of MDR1 and LAPTM4B expression in their 343 blood. This finding is supported by the study of Li and co-workers that showed a high level of 344 MDR1 and LAPTM4B expression in metastatic breast cancer correlated with resistance to anthracycline-based chemotherapy regimen (Li et al. 1998). In another study of Fan et al., 2012 found that expression of LAPTM4B is related to risk of breast cancer development in Chinese women group.

In ovarian cancer, we observed an association of elevated HIF-1 $\alpha$, MDR1 and LAPTM4B expression with advance tumor stage, metastasis and pre-treated. Previously in-vitro studies in ovarian cancer cell lines, conducted by Qin et al., have reported chemotherapy resistance with elevated HIF-1 $\alpha$ expression (Qin et al. 2017). A meta-analysis reported by Jin et al., showed increased expression of HIF-1 $\alpha$ is observed in malignant compared to benign tumors (Jin et al. 2014). They also reported high expression of HIF-1 $\alpha$ in stage III-IV along with metastasis as compared to stage I-II as well as without metastasis (Jin et al. 2014). High level of MDR1 mRNA level in patients treating with chemotherapeutic regimen that contains at least one P-gp substrate was reported (Holzmayer et al. 1992). MDR1 is involved in resistance to platinum-based chemotherapeutics in ovarian cancer cell lines (Sonego et al. 2017). Yin and colleagues found an association of LAPTM4B expression with stage III and chemotherapy resistance in patients who are taking PAC (cisplatin, epirubicin and cyclophosphamide) regimen in ovarian cancer (Yin et al. 2011). In the present study patients are receiving the platinum-based chemotherapy (cisplatin or carboplatin) hence they develop resistance to these agents. Yang et al., 2008 also reported that elevated expression of LAPTM4B is associated with advanced tumor stage, and it is neither correlated with age not with gender in 85 ovarian cancer tissue samples which shows that 
In prostate cancer, we observed an association of increased HIF-1 $\alpha$ and LAPTM4B

366

367

368

369

370

371

372

373

374

375

376

377

378

379

380

381

382

383

384

385

386

387

388

389

390

391

392

393

394

395

expression with advanced tumor stage and metastasis. No correlation of MDR1 was observed with tumor stage and metastasis. In case of LAPTM4B, no correlation was observed with chemotherapy treatment and this may be due to small sample size of the study. We observed increased expression of HIF-1 $\alpha$ and MDR1 in patients who were under the chemotherapy treatment. Our results showed similar findings compared to previous studies on the expression of HIF-1 $\alpha$ in prostate cancer. Wang et al., found a significant correlation of HIF-1 $\alpha$ expression with metastasis (Wang et al. 2006). Fojo et al., identified the low level of P-gp expression in normal prostate tissue while Valk et al., reported high level (MDR1) in prostate cancer (van der Valk et al. 1990). Contrary to our results Izbicka et al., observed high MDR1 mRNA expression in metastatic prostate cancer patients as compared to localized disease stage (Izbicka et al. 1998). Previously, the association of high LAPTM4B expression was observed with poor prognosis, high TNM stage, lymph node metastasis, and seminal vesicle invasion in prostate cancer patients. In general high LAPTM4B expression is shown to be associated with poor prognosis in prostate cancer (Zhang et al. 2014).

In colonic cancer patients, a similar trend was observed where high HIF-1 $\alpha$, MDR1 and LAPTM4B expression was correlated with advanced tumor stage, metastasis as well as chemotherapy treatment in isolated studies. Mansour et al., studied the similar trend where high HIF-1 $\alpha$ expression directs towards advance stages (Mansour et al. 2016). Kang and co-workers studied the expression of LAPTM4B in colon cancer tissue samples and found a high expression compared to controls (Kang et al. 2012).

This study also analyzed any potential mutual correlation patterns observed among HIF1 $\alpha$, MDR1 and LAPTM4B. The Spearman correlation analysis suggested the HIF-1 $\alpha$ expression to be significantly associated with increased MDR1 and LAPTM4B expression in breast, ovarian, colon and prostate cancer patients. These results are consistent with previous findings where high expression of MDR1 and HIF-1 $\alpha$ associated with tumor stage and metastasis in colon cancer and lung small cell carcinoma. Hence these two proteins may be considered as potential candidate biomarkers for predicting the malignant progression and metastasis of human colon and LSCC (Ding et al. 2010; Xie et al. 2013). It has been reported previously that LAPTM4B regulates expression of MDR1 through activation of PI3K/AKT pathway (Li et al. 2010). As the synthesis of $\mathrm{HIF}-1 \alpha$ is also regulated through PI3K/AKT pathway hence LAPTM4B also regulated expression of HIF-1 $\alpha$. 
Our study results were limited by the unavailability of verified survival data and lost to

397

398

399

400

401

402

403

404

405

406

407

408

409

410

411

412

413

414

415

416

417

418

419

420

421

422

423

424

425

follow up status of the patients recruited in this study which may have broaden our results validity.

The ever evolving face of intra-tumoral heterogeneity has continued the quest for circulating biomarkers for cancer prognosis, however recent reports have supplement to potential consideration list the DNA biomarkers like BRAF, PIK3CA, MGMT, KRAS, TP53, circulating tumor DNA and RNA biomarkers like miR-155, miR21-5p, miR125b-5p, miR200, miR210 and miR221(Rapisuwon et al. 2016). However, none of them have proven to be clinically conclusive for all cancers or even for all solid tumors. This study provides preliminary evidence directing towards the utilization of co-expressional profiles of HIF-1 $\alpha$, MDR1 and LAPTM4B as potential candidate for serum based biomarkers for tumor progression however warranting further clinical surveillance. Moreover, further studies with bigger patient cohort will be required to elaborate the prognostic role of HIF1, MDR and LAPTM4B in all solid tumors. To add further, the new evidence stemming from this study contributes to the addition of our understanding of LAPTM4B in cancer development and progression. Furthermore, LAPTM4B as a mediator of hypoxia induced autophagy provides cyto-protection and contribution in evading chemotherapeutic drug response (Li et al. 2011), which can be further investigated as a therapeutic target in this context.

\section{Conclusion:}

In the current study, we identified a high level of expression of HIF-1 $\alpha$, MDR1 and LAPTM4B in peripheral blood of representative solid tumor patient's samples. The high expression of these genes has been found to be associated with disease progression. The reflection of peripheral blood expression of these genes in solid tumor patients may serve to further establish these genes as potential circulating biomarker for cancer prognosis and therefore by attributing the functional significance of HIF-1 $\alpha$, MDR1 and LAPTM4B, addition of angiogenic inhibitors coupled with autophagy inhibitors may synergistically aid in the effective therapy and prevent drug resistance.

\section{References:}

Badowska-Kozakiewicz AM, Sobol M, and Patera J. 2017. Expression of multidrug resistance protein Pglycoprotein in correlation with markers of hypoxia (HIF-1alpha, EPO, EPO-R) in invasive breast cancer with metastasis to lymph nodes. Arch Med Sci 13:1303-1314. 10.5114/aoms.2016.62723 
433

434

435

436

437

438

439

440

441

442

443

444

445

446

447

448

449

450

451

452

453

454

455

456

457

458

459

460

461

462

463

464

465

466

467

468

469

28478 [pii]

Bedard PL, Hansen AR, Ratain MJ, and Siu LL. 2013. Tumour heterogeneity in the clinic. Nature 501:355364. 10.1038/nature12627

nature12627 [pii]

Benita Y, Kikuchi H, Smith AD, Zhang MQ, Chung DC, and Xavier RJ. 2009. An integrative genomics approach identifies Hypoxia Inducible Factor-1 (HIF-1)-target genes that form the core response to hypoxia. Nucleic Acids Res 37:4587-4602. 10.1093/nar/gkp425

gkp425 [pii]

Bhangal G, Halford S, Wang J, Roylance R, Shah R, and Waxman J. 2000. Expression of the multidrug resistance gene in human prostate cancer. Urol Oncol 5:118-121. S1078-1439(99)00055-1 [pii]

Bos R, van der Groep P, Greijer AE, Shvarts A, Meijer S, Pinedo HM, Semenza GL, van Diest PJ, and van der Wall E. 2003. Levels of hypoxia-inducible factor-1alpha independently predict prognosis in patients with lymph node negative breast carcinoma. Cancer 97:1573-1581. 10.1002/cncr.11246

Brown JM, and Giaccia AJ. 1998. The unique physiology of solid tumors: opportunities (and problems) for cancer therapy. Cancer Res 58:1408-1416.

Burger H, Foekens JA, Look MP, Meijer-van Gelder ME, Klijn JG, Wiemer EA, Stoter G, and Nooter K. 2003. RNA expression of breast cancer resistance protein, lung resistance-related protein, multidrug resistance-associated proteins 1 and 2, and multidrug resistance gene 1 in breast cancer: correlation with chemotherapeutic response. Clin Cancer Res 9:827-836.

Cheng X, Tian X, Wu X, Xing X, Du H, Zhou C, Zhang Q, Hao C, Wen X, and Ji J. 2016. Relationship between LAPTM4B Gene Polymorphism and Prognosis of Patients following Tumor Resection for Colorectal and Esophageal Cancers. PLoS One 11:e0158715. 10.1371/journal.pone.0158715

PONE-D-16-07158 [pii]

Dales JP, Garcia S, Meunier-Carpentier S, Andrac-Meyer L, Haddad O, Lavaut MN, Allasia C, Bonnier P, and Charpin C. 2005. Overexpression of hypoxia-inducible factor HIF-1alpha predicts early relapse in breast cancer: retrospective study in a series of 745 patients. Int J Cancer 116:734739. 10.1002/ijc.20984

Dielschneider RF, Henson ES, and Gibson SB. 2017. Lysosomes as Oxidative Targets for Cancer Therapy. Oxid Med Cell Longev 2017:3749157. 10.1155/2017/3749157

Ding Z, Yang L, Xie X, Xie F, Pan F, Li J, He J, and Liang H. 2010. Expression and significance of hypoxiainducible factor-1 alpha and MDR1/P-glycoprotein in human colon carcinoma tissue and cells. $J$ Cancer Res Clin Oncol 136:1697-1707. 10.1007/s00432-010-0828-5

Futter CE, Collinson LM, Backer JM, and Hopkins CR. 2001. Human VPS34 is required for internal vesicle formation within multivesicular endosomes. J Cell Biol 155:1251-1264. 10.1083/jcb.200108152

jcb.200108152 [pii]

Generali D, Berruti A, Brizzi MP, Campo L, Bonardi S, Wigfield S, Bersiga A, Allevi G, Milani M, Aguggini S, Gandolfi V, Dogliotti L, Bottini A, Harris AL, and Fox SB. 2006. Hypoxia-inducible factor-1alpha expression predicts a poor response to primary chemoendocrine therapy and disease-free survival in primary human breast cancer. Clin Cancer Res 12:4562-4568. 12/15/4562 [pii]

10.1158/1078-0432.CCR-05-2690

Gerlinger M, Rowan AJ, Horswell S, Math M, Larkin J, Endesfelder D, Gronroos E, Martinez P, Matthews N, Stewart A, Tarpey P, Varela I, Phillimore B, Begum S, McDonald NQ, Butler A, Jones D, Raine K, Latimer C, Santos CR, Nohadani M, Eklund AC, Spencer-Dene B, Clark G, Pickering L, Stamp G, Gore M, Szallasi Z, Downward J, Futreal PA, and Swanton C. 2012. Intratumor heterogeneity and 
470

471

472

473

474

475

476

477

478

479

480

481

482

483

484

485

486

487

488

489

490

491

492

493

494

495

496

497

498

499

500

501

502

503

504

505

506

507

508

509

510

511

512

513

branched evolution revealed by multiregion sequencing. N Engl J Med 366:883-892. 10.1056/NEJMoa1113205

Gnatenko DV, Zhu W, Xu X, Samuel ET, Monaghan M, Zarrabi MH, Kim C, Dhundale A, and Bahou WF. 2010. Class prediction models of thrombocytosis using genetic biomarkers. Blood 115:7-14. 10.1182/blood-2009-05-224477

blood-2009-05-224477 [pii]

Gottesman MM, Fojo T, and Bates SE. 2002. Multidrug resistance in cancer: role of ATP-dependent transporters. Nat Rev Cancer 2:48-58. 10.1038/nrc706

Gruber G, Greiner RH, Hlushchuk R, Aebersold DM, Altermatt HJ, Berclaz G, and Djonov V. 2004. Hypoxia-inducible factor 1 alpha in high-risk breast cancer: an independent prognostic parameter? Breast Cancer Res 6:R191-198. 10.1186/bcr775

bcr775 [pii]

Hewitson KS, Lienard BM, McDonough MA, Clifton IJ, Butler D, Soares AS, Oldham NJ, McNeill LA, and Schofield CJ. 2007. Structural and mechanistic studies on the inhibition of the hypoxia-inducible transcription factor hydroxylases by tricarboxylic acid cycle intermediates. J Biol Chem 282:32933301. M608337200 [pii]

10.1074/jbc.M608337200

Holzmayer TA, Hilsenbeck S, Von Hoff DD, and Roninson IB. 1992. Clinical correlates of MDR1 (Pglycoprotein) gene expression in ovarian and small-cell lung carcinomas. J Nat/ Cancer Inst 84:1486-1491.

Huygens C, Lienart S, Dedobbeleer O, Stockis J, Gauthy E, Coulie PG, and Lucas S. 2015. Lysosomalassociated Transmembrane Protein 4B (LAPTM4B) Decreases Transforming Growth Factor beta1 (TGF-beta1) Production in Human Regulatory T Cells. J Biol Chem 290:20105-20116. 10.1074/jbc.M115.655340

M115.655340 [pii]

Izbicka E, Dalton WS, Troyer D, and Von Hoff DD. 1998. Expression of two multidrug resistance genes in human prostatic carcinomas. J Natl Cancer Inst 90:166-167.

Jakabova A, Bielcikova Z, Pospisilova E, Matkowski R, Szynglarewicz B, Staszek-Szewczyk U, Zemanova M, Petruzelka L, Eliasova P, Kolostova K, and Bobek V. 2017. Molecular characterization and heterogeneity of circulating tumor cells in breast cancer. Breast Cancer Res Treat 166:695-700. 10.1007/s10549-017-4452-9

10.1007/s10549-017-4452-9 [pii]

Jiang F, Jin T, Feng XL, Jin QF, and Chen XZ. 2016. Repeat biopsy of primary disease negatively affects the outcome of patients with nasopharyngeal cancer treated with definitive intensity-modified radiotherapy: a cohort analysis of 795 patients. Jpn J Clin Oncol 46:435-440. 10.1093/jjco/hyw003

hyw003 [pii]

Jin Y, Wang H, Liang X, Ma J, and Wang Y. 2014. Pathological and prognostic significance of hypoxiainducible factor 1alpha expression in epithelial ovarian cancer: a meta-analysis. Tumour Biol 35:8149-8159. 10.1007/s13277-014-2059-x

Kallergi G, Markomanolaki H, Giannoukaraki V, Papadaki MA, Strati A, Lianidou ES, Georgoulias V, Mavroudis D, and Agelaki S. 2009. Hypoxia-inducible factor-1alpha and vascular endothelial growth factor expression in circulating tumor cells of breast cancer patients. Breast Cancer Res 11:R84. 10.1186/bcr2452 
514

515

516

517

518

519

520

521

522

523

524

525

526

527

528

529

530

531

532

533

534

535

536

537

538

539

540

541

542

543

544

545

546

547

548

549

550

551

552

553

554

555

556

bcr2452 [pii]

Kang $\mathrm{Y}$, Yin M, Jiang $\mathrm{W}$, Zhang $\mathrm{H}, \mathrm{Xia} \mathrm{B}$, Xue $\mathrm{Y}$, and Huang Y. 2012. Overexpression of LAPTM4B-35 is associated with poor prognosis in colorectal carcinoma. Am J Surg 204:677-683. 10.1016/j.amjsurg.2012.02.003

S0002-9610(12)00192-4 [pii]

Koh MY, and Powis G. 2012. Passing the baton: the HIF switch. Trends Biochem Sci 37:364-372. 10.1016/j.tibs.2012.06.004

S0968-0004(12)00079-5 [pii]

Koivunen P, Hirsila M, Remes AM, Hassinen IE, Kivirikko KI, and Myllyharju J. 2007. Inhibition of hypoxiainducible factor (HIF) hydroxylases by citric acid cycle intermediates: possible links between cell metabolism and stabilization of HIF. J Biol Chem 282:4524-4532. M610415200 [pii]

10.1074/jbc.M610415200

Krishnamachary B, Berg-Dixon S, Kelly B, Agani F, Feldser D, Ferreira G, Iyer N, LaRusch J, Pak B, Taghavi $P$, and Semenza GL. 2003. Regulation of colon carcinoma cell invasion by hypoxia-inducible factor 1. Cancer Res 63:1138-1143.

LaGory EL, and Giaccia AJ. 2016. The ever-expanding role of HIF in tumour and stromal biology. Nat Cell Biol 18:356-365. 10.1038/ncb3330

ncb3330 [pii]

Lai MC, Chang CM, and Sun HS. 2016. Hypoxia Induces Autophagy through Translational Up-Regulation of Lysosomal Proteins in Human Colon Cancer Cells. PLoS One 11:e0153627. 10.1371/journal.pone.0153627

PONE-D-15-48051 [pii]

Lee YM, Chang WC, and Ma WL. 2016. Hypothesis: solid tumours behave as systemic metabolic dictators. J Cell Mol Med 20:1076-1085. 10.1111/jcmm.12794

Li E, Li R, and Zhang Z. 1998. [Clinical significance of P-glycoprotein expression in breast cancer]. Zhonghua Zhong Liu Za Zhi 20:371-373.

Li L, Wei XH, Pan YP, Li HC, Yang H, He QH, Pang Y, Shan Y, Xiong FX, Shao GZ, and Zhou RL. 2010. LAPTM4B: a novel cancer-associated gene motivates multidrug resistance through efflux and activating PI3K/AKT signaling. Oncogene 29:5785-5795. 10.1038/onc.2010.303

onc2010303 [pii]

Li Y, Zhang Q, Tian R, Wang Q, Zhao JJ, Iglehart JD, Wang ZC, and Richardson AL. 2011. Lysosomal transmembrane protein LAPTM4B promotes autophagy and tolerance to metabolic stress in cancer cells. Cancer Res 71:7481-7489. 10.1158/0008-5472.CAN-11-0940

0008-5472.CAN-11-0940 [pii]

Liu X, Zhou R, Zhang Q, Zhang Y, Shao G, Jin Y, Zhang S, Lin M, Rui J, and Ye D. 2003. [Identification and characterization of LAPTM4B encoded by a human hepatocellular carcinoma-associated novel gene]. Beijing Da Xue Xue Bao Yi Xue Ban 35:340-347.

Liu Y, Tang J, Hu Q, Lu K, and Hou C. 2018. A preliminary study on the expression and clinical value of platelet-derived growth factor BB, hypoxia inducible factor-1a and C-C motif chemokine receptor-2 in peripheral blood during the pathogenesis of Graves' disease. Endokrynologia Polska 69:9 - 15. 10.5603/EP.a2018.0004

Lu L, Katsaros D, Wiley A, Rigault de la Longrais IA, Puopolo M, and Yu H. 2007. Expression of MDR1 in epithelial ovarian cancer and its association with disease progression. Oncol Res 16:395-403. 
557

558

559

560

561

562

563

564

565

566

567

568

569

570

571

572

573

574

575

576

577

578

579

580

581

582

583

584

585

586

587

588

589

590

591

592

593

594

595

596

597

598

599

Lu LS, Chen L, Ding WX, Li K, and Wu JJ. 2012. Elevated expression of both MDR1 and MMP-2 genes in metastasized lymph node of invasive ductal breast cancer. Eur Rev Med Pharmacol Sci 16:20372043.

Luo Y, Bian Z, Ye G, Yu M, Wang Z, Qin S, Mu Y, and Zhong M. 2015. [Impact of lysosome-associated protein transmembrane-4 beta on proliferation and invasion of colorectal cancer]. Zhonghua Wei Chang Wai Ke Za Zhi 18:606-610. 100001882012 [pii]

Ma J, Chen C, Barth AS, Cheadle C, Guan X, and Gao L. 2015. Lysosome and Cytoskeleton Pathways Are Robustly Enriched in the Blood of Septic Patients: A Meta-Analysis of Transcriptomic Data. Mediators Inflamm 2015:984825. 10.1155/2015/984825

Manalo DJ, Rowan A, Lavoie T, Natarajan L, Kelly BD, Ye SQ, Garcia JG, and Semenza GL. 2005. Transcriptional regulation of vascular endothelial cell responses to hypoxia by HIF-1. Blood 105:659-669. 10.1182/blood-2004-07-2958

2004-07-2958 [pii]

Mansour RN, Enderami SE, Ardeshirylajimi A, Fooladsaz K, Fathi M, and Ganji SM. 2016. Evaluation of hypoxia inducible factor-1 alpha gene expression in colorectal cancer stages of Iranian patients. $J$ Cancer Res Ther 12:1313-1317. 10.4103/0973-1482.199542

JCanResTher_2016_12_4_1313_199542 [pii]

Mo C, Lu Y, Deng Y, Wang J, Xie L, Li T, He Y, Peng Q, Qin X, and Li S. 2014. LAPTM4B polymorphism increases susceptibility to multiple cancers in Chinese populations: a meta-analysis. BMC Genet 15:48. 10.1186/1471-2156-15-48

1471-2156-15-48 [pii]

Nanayakkara AK, Follit CA, Chen G, Williams NS, Vogel PD, and Wise JG. 2018. Targeted inhibitors of Pglycoprotein increase chemotherapeutic-induced mortality of multidrug resistant tumor cells. Sci Rep 8:967. 10.1038/s41598-018-19325-x

10.1038/s41598-018-19325-x [pii]

Parissenti AM, Gannon BR, Villeneuve DJ, Kirwan-rhude AF, Chadderton A, and Gluck S. 1999. Lack of modulation of MDR1 gene expression by dominant inhibition of CAMP-dependent protein kinase in doxorubicin-resistant MCF-7 breast cancer cells. Int J Cancer 82:893-900. 10.1002/(SICI)10970215(19990909)82:6<893::AID-IJC20>3.0.CO;2-8 [pii]

Pipinikas CP, Carter ND, Corbishley CM, and Fenske CD. 2008. HIF-1alpha mRNA gene expression levels in improved diagnosis of early stages of prostate cancer. Biomarkers 13:680-691. $10.1080 / 13547500802591992$

906979405 [pii]

Pollard PJ, Briere JJ, Alam NA, Barwell J, Barclay E, Wortham NC, Hunt T, Mitchell M, Olpin S, Moat SJ, Hargreaves IP, Heales SJ, Chung YL, Griffiths JR, Dalgleish A, McGrath JA, Gleeson MJ, Hodgson SV, Poulsom R, Rustin P, and Tomlinson IP. 2005. Accumulation of Krebs cycle intermediates and over-expression of HIF1alpha in tumours which result from germline $\mathrm{FH}$ and SDH mutations. Hum Mol Genet 14:2231-2239. ddi227 [pii]

$10.1093 / \mathrm{hmg} / \mathrm{ddi} 227$

Qin J, Liu Y, Lu Y, Liu M, Li M, Li J, and Wu L. 2017. Hypoxia-inducible factor 1 alpha promotes cancer stem cells-like properties in human ovarian cancer cells by upregulating SIRT1 expression. Sci Rep 7:10592. 10.1038/s41598-017-09244-8

10.1038/s41598-017-09244-8 [pii] 
600

601

602

603

604

605

606

607

608

609

610

611

612

613

614

615

616

617

618

619

620

621

622

623

624

625

626

627

628

629

630

631

632

633

634

635

636

637

638

639

640

641
Rapisuwon S, Vietsch EE, and Wellstein A. 2016. Circulating biomarkers to monitor cancer progression and treatment. Comput Struct Biotechnol J 14:211-222. 10.1016/j.csbj.2016.05.004

S2001-0370(16)30011-3 [pii]

Robey RW, Zhan Z, Piekarz RL, Kayastha GL, Fojo T, and Bates SE. 2006. Increased MDR1 expression in normal and malignant peripheral blood mononuclear cells obtained from patients receiving depsipeptide (FR901228, FK228, NSC630176). Clin Cancer Res 12:1547-1555. 12/5/1547 [pii]

\subsection{8/1078-0432.CCR-05-1423}

Saksena S, Wahlman J, Teis D, Johnson AE, and Emr SD. 2009. Functional reconstitution of ESCRT-III assembly and disassembly. Cell 136:97-109. 10.1016/j.cell.2008.11.013

S0092-8674(08)01442-6 [pii]

Schinkel AH, Smit JJ, van Tellingen O, Beijnen JH, Wagenaar E, van Deemter L, Mol CA, van der Valk MA, Robanus-Maandag EC, te Riele HP, Berns AJM and Borst P. 1994. Disruption of the mouse mdr1a P-glycoprotein gene leads to a deficiency in the blood-brain barrier and to increased sensitivity to drugs. Cell 77:491-502. 0092-8674(94)90212-7 [pii]

Semenza GL. 2012. Hypoxia-inducible factors in physiology and medicine. Cell 148:399-408. 10.1016/j.cell.2012.01.021

S0092-8674(12)00087-6 [pii]

Shaker O, Taha F, Salah M, and El-Marzouky M. 2015. LAPTM4B Gene Expression and Polymorphism as Diagnostic Markers of Breast Cancer in Egyptian Patients. J Med Biochem 34:393-401. 10.2478/jomb-2014-0067

jomb-2014-0067 [pii]

Shao GZ, Zhou RL, Zhang QY, Zhang Y, Liu JJ, Rui JA, Wei X, and Ye DX. 2003. Molecular cloning and characterization of LAPTM4B, a novel gene upregulated in hepatocellular carcinoma. Oncogene 22:5060-5069. 10.1038/sj.onc.1206832

1206832 [pii]

Sholl LM, Aisner DL, Allen TC, Beasley MB, Cagle PT, Capelozzi VL, Dacic S, Hariri LP, Kerr KM, Lantuejoul S, Mino-Kenudson M, Raparia K, Rekhtman N, Roy-Chowdhuri S, Thunnissen E, Tsao M, Vivero $M$, and Yatabe Y. 2016. Liquid Biopsy in Lung Cancer: A Perspective From Members of the Pulmonary Pathology Society. Arch Pathol Lab Med 140:825-829. 10.5858/arpa.2016-0163-SA

Sonego M, Pellizzari I, Dall'Acqua A, Pivetta E, Lorenzon I, Benevol S, Bomben R, Spessotto P, Sorio R, Gattei V, Belletti B, Schiappacassi M, and Baldassarre G. 2017. Common biological phenotypes characterize the acquisition of platinum-resistance in epithelial ovarian cancer cells. Sci Rep 7:7104. 10.1038/s41598-017-07005-1

10.1038/s41598-017-07005-1 [pii]

Szakacs G, Annereau JP, Lababidi S, Shankavaram U, Arciello A, Bussey KJ, Reinhold W, Guo Y, Kruh GD, Reimers M, Weinstein JN, and Gottesman MM. 2004. Predicting drug sensitivity and resistance: profiling ABC transporter genes in cancer cells. Cancer Cell 6:129-137. 10.1016/j.ccr.2004.06.026

\section{S1535610804002065 [pii]}

Talks KL, Turley H, Gatter KC, Maxwell PH, Pugh CW, Ratcliffe PJ, and Harris AL. 2000. The expression and distribution of the hypoxia-inducible factors HIF-1alpha and HIF-2alpha in normal human tissues, cancers, and tumor-associated macrophages. Am J Pathol 157:411-421. S0002-9440(10)64554-3 [pii] 
642

643

644

645

646

647

648

649

650

651

652

653

654

655

656

657

658

659

660

661

662

663

664

665

666

667

668

669

670

671

672

673

674

675

676

677

678

679

680

681

682

683

684
Tang H, Tian H, Yue W, Li L, Li S, Gao C, Si L, Qi L, and Lu M. 2014. Overexpression of LAPTM4B is correlated with tumor angiogenesis and poor prognosis in non-small cell lung cancer. Med Oncol 31:974. 10.1007/s12032-014-0974-8

Teicher BA. 1994. Hypoxia and drug resistance. Cancer Metastasis Rev 13:139-168.

van der Valk P, van Kalken CK, Ketelaars H, Broxterman HJ, Scheffer G, Kuiper CM, Tsuruo T, Lankelma J, Meijer CJ, Pinedo HM, and Scheper RJ. 1990. Distribution of multi-drug resistance-associated Pglycoprotein in normal and neoplastic human tissues. Analysis with 3 monoclonal antibodies recognizing different epitopes of the P-glycoprotein molecule. Ann Oncol 1:56-64.

Veneroni S, Zaffaroni N, Daidone MG, Benini E, Villa R, and Silvestrini R. 1994. Expression of Pglycoprotein and in vitro or in vivo resistance to doxorubicin and cisplatin in breast and ovarian cancers. Eur J Cancer 30A:1002-1007. 0959-8049(94)90132-5 [pii]

Wang GL, and Semenza GL. 1993. General involvement of hypoxia-inducible factor 1 in transcriptional response to hypoxia. Proc Natl Acad Sci U S A 90:4304-4308.

Wang L, Chen ZJ, Wang QT, Cao WF, Jian Y, Wang SX, and Zhang BH. 2006. [Expression of hypoxiainducible factor 1 alpha and vascular endothelial growth factor in prostate cancer and its significance]. Zhonghua Nan Ke Xue 12:57-59.

Wigerup C, Pahlman S, and Bexell D. 2016. Therapeutic targeting of hypoxia and hypoxia-inducible factors in cancer. Pharmacol Ther 164:152-169. 10.1016/j.pharmthera.2016.04.009

S0163-7258(16)30055-9 [pii]

Xia Z, Zhu Z, Zhang L, Royal C, Liu Z, Chen Q, and Adam BL. 2008. Specific reversal of MDR1/P-gpdependent multidrug resistance by RNA interference in colon cancer cells. Oncol Rep 20:14331439.

Xiao M, Jia S, Wang H, Wang J, Huang Y, and Li Z. 2013. Overexpression of LAPTM4B: an independent prognostic marker in breast cancer. J Cancer Res Clin Oncol 139:661-667. 10.1007/s00432-0121368-y

Xie J, Li DW, Chen XW, Wang F, and Dong P. 2013. Expression and significance of hypoxia-inducible factor-1alpha and MDR1/P-glycoprotein in laryngeal carcinoma tissue and hypoxic Hep-2 cells. Oncol Lett 6:232-238. 10.3892/ol.2013.1321

ol-06-01-0232 [pii]

Yang H, Xiong F, Wei X, Yang Y, McNutt MA, and Zhou R. 2010. Overexpression of LAPTM4B-35 promotes growth and metastasis of hepatocellular carcinoma in vitro and in vivo. Cancer Lett 294:236-244. 10.1016/j.canlet.2010.02.006

S0304-3835(10)00094-7 [pii]

Yang Y, Yang H, McNutt MA, Xiong F, Nie X, Li L, and Zhou R. 2008. LAPTM4B overexpression is an independent prognostic marker in ovarian carcinoma. Oncol Rep 20:1077-1083.

Yang Y, Zhang Y, Iwamoto H, Hosaka K, Seki T, Andersson P, Lim S, Fischer C, Nakamura M, Abe M, Cao R, Skov PV, Chen F, Chen X, Lu Y, Nie G, and Cao Y. 2016. Discontinuation of anti-VEGF cancer therapy promotes metastasis through a liver revascularization mechanism. Nat Commun 7:12680. 10.1038/ncomms 12680

ncomms12680 [pii]

Yin M, Xu Y, Lou G, Hou Y, Meng F, Zhang H, Li C, and Zhou R. 2011. LAPTM4B overexpression is a novel predictor of epithelial ovarian carcinoma metastasis. Int J Cancer 129:629-635. 10.1002/ijc.25689 
685

686

687

688

689

690

691

692

693

694

695

696

697

698

699

700

701

702
Zhang H, Wei Q, Liu R, Qi S, Liang P, Qi C, Wang A, Sheng B, Li L, and Xu Y. 2014. Overexpression of LAPTM4B-35: a novel marker of poor prognosis of prostate cancer. PLoS One 9:e91069. 10.1371/journal.pone.0091069

PONE-D-13-34256 [pii]

Zhang Y, Shi Y, Li X, Du R, Luo G, Xia L, Du W, Chen B, Zhai H, Wu K, and Fan D. 2008. Proteasome inhibitor MG132 reverses multidrug resistance of gastric cancer through enhancing apoptosis and inhibiting P-gp. Cancer Biol Ther 7:540-546. 5483 [pii]

Zhong H, De Marzo AM, Laughner E, Lim M, Hilton DA, Zagzag D, Buechler P, Isaacs WB, Semenza GL, and Simons JW. 1999. Overexpression of hypoxia-inducible factor 1alpha in common human cancers and their metastases. Cancer Res 59:5830-5835.

Zhou L, He XD, Yu JC, Zhou RL, Yang H, Qu Q, and Rui JA. 2010. Overexpression of LAPTM4B promotes growth of gallbladder carcinoma cells in vitro. Am J Surg 199:515-521. 10.1016/j.amjsurg.2009.03.031

S0002-9610(09)00509-1 [pii]

Zimna A, and Kurpisz M. 2015. Hypoxia-Inducible Factor-1 in Physiological and Pathophysiological Angiogenesis: Applications and Therapies. Biomed Res Int 2015:549412. 10.1155/2015/549412 


\section{Table $\mathbf{1}$ (on next page)}

Clinicopathological features of cancerous patients enrolled in the study. The N shows the number of patients in each group. 
1 Table 1: Clinicopathological features of cancerous patients enrolled in the study. The N shows the number of patients in each group.

\begin{tabular}{|c|c|c|c|c|c|}
\hline \multicolumn{2}{|c|}{$\begin{array}{c}\text { Clinicopathological characteristics } \\
\text { of patients }\end{array}$} & $\begin{array}{c}\text { Breast Cancer } \\
(\mathrm{N})(\%)\end{array}$ & $\begin{array}{c}\text { Ovarian Cancer } \\
\text { (N) (\%) }\end{array}$ & $\begin{array}{c}\text { Prostate Cancer } \\
\text { (N) }(\%)\end{array}$ & $\begin{array}{c}\text { Colon Cancer } \\
\text { (N) (\%) }\end{array}$ \\
\hline & $\leq 50$ & $46(63.8)$ & $26(61.9)$ & $0(0)$ & $20(62.5)$ \\
\hline \multirow[t]{2}{*}{ Age } & $>50$ & $26(36.1)$ & $16(38.0)$ & $21(100)$ & $12(37.5)$ \\
\hline & I-II & $16(22.2)$ & $12(28.5)$ & $6(28.5)$ & $13(40.6)$ \\
\hline Stage & III-IV & $56(77.7)$ & $30(71.4)$ & $15(71.4)$ & $19(59.3)$ \\
\hline \multirow[t]{2}{*}{ Metastasis } & Metastatic & $51(70.8)$ & $28(66.6)$ & $13(61.9)$ & $21(65.6)$ \\
\hline & Non-metastatic & $21(29.1)$ & $14(33.3)$ & $8(38.0)$ & $11(34.3)$ \\
\hline \multirow[t]{2}{*}{ Treatment } & Pre-treated & $57(79.1)$ & $34(80.9)$ & $14(66.6)$ & $19(59.3)$ \\
\hline & Treatment naïve & $15(20.8)$ & $8(19.0)$ & $7(33.3)$ & $13(40.6)$ \\
\hline
\end{tabular}

3 


\section{Table 2 (on next page)}

Correlation of HIF-1 $\alpha$, MDR1, and LAPTM4B expression with clinico-pathological features of Breast cancer. The $\mathrm{N}$ shows the number of patients in each group. Where $\mathrm{p}$ value describes the significance and $p<0.05$ shows the significance of results. 


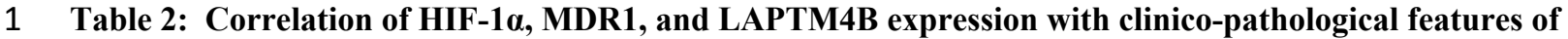
2 Breast cancer. The $\mathbf{N}$ shows the number of patients in each group. Where $p$ value describes the significance 3 and $p<0.05$ shows the significance of results.

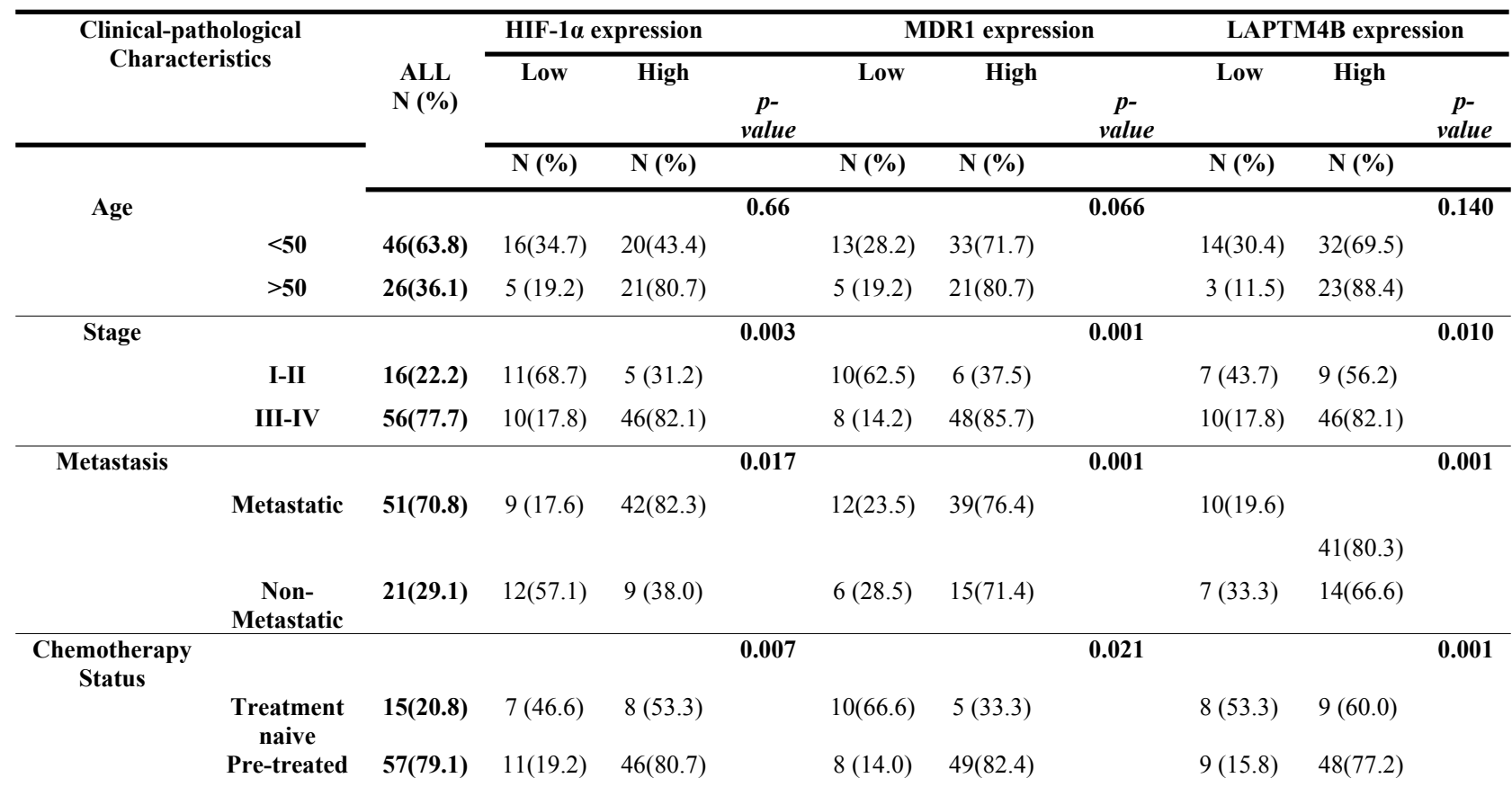

4 


\section{Table 3(on next page)}

Correlation of HIF-1 $\alpha$, MDR1, and LAPTM4B expression with clinico-pathological features of ovarian cancer. The $\mathrm{N}$ shows the number of patients in each group. Where $\mathrm{p}$ value describes the significance and $p<0.05$ shows the significance of results. 
1 Table 3: Correlation of HIF-1 $\alpha$, MDR1, and LAPTM4B expression with clinico-pathological features of ovarian cancer. The $\mathbf{N}$ shows the number of patients in each group. Where $p$ value describes the significance and $\mathbf{p}<0.05$ shows the significance of results.

\begin{tabular}{|c|c|c|c|c|c|c|c|c|c|c|c|}
\hline \multirow{2}{*}{\multicolumn{2}{|c|}{$\begin{array}{l}\text { Clinical-pathological } \\
\text { Characteristics }\end{array}$}} & \multirow{4}{*}{$\begin{array}{l}\text { ALL } \\
\text { N (\%) }\end{array}$} & \multirow{2}{*}{\multicolumn{2}{|c|}{$\begin{array}{c}\text { HIF-1a } \\
\text { expression }\end{array}$}} & & \multirow{2}{*}{\multicolumn{3}{|c|}{ MDR1 expression }} & \multicolumn{3}{|c|}{ LAPTM4B expression } \\
\hline & & & & & \multirow{3}{*}{$\begin{array}{c}p- \\
\text { value }\end{array}$} & & & & & & \\
\hline & & & \multirow{2}{*}{$\begin{array}{c}\text { Low } \\
\text { N (\%) }\end{array}$} & \multirow{2}{*}{$\begin{array}{c}\text { High } \\
\text { N (\%) }\end{array}$} & & Low & High & \multirow[t]{2}{*}{ p-value } & Low & High & \multirow[t]{2}{*}{$\begin{array}{c}p- \\
\text { value }\end{array}$} \\
\hline & & & & & & $\mathbf{N}(\%)$ & $\mathbf{N}(\%)$ & & $\mathbf{N}(\%)$ & $\mathbf{N}(\%)$ & \\
\hline \multirow[t]{3}{*}{ Age } & & & & & 0.700 & & & 0.181 & & & 0.115 \\
\hline & $<\mathbf{5 0}$ & 26(61.9) & $7(26.9)$ & $19(73.0)$ & & $11(42.3)$ & $15(57.6)$ & & $9(34.6)$ & $17(65.3)$ & \\
\hline & $>\mathbf{5 0}$ & $16(38.0)$ & $3(18.7)$ & $13(81.2)$ & & $4(25.0)$ & $12(75.0)$ & & $3(18.7)$ & $13(81.2)$ & \\
\hline \multirow[t]{3}{*}{ Stage } & & & & & 0.030 & & & 0.010 & & & 0.001 \\
\hline & I-II & $12(28.5)$ & $4(33.3)$ & $8(66.6)$ & & $7(58.3)$ & $5(41.6)$ & & $6(50.0)$ & $6(50.0)$ & \\
\hline & III-IV & $30(71.4)$ & $6(20.0)$ & $24(80.0)$ & & $8(26.6)$ & $22(73.3)$ & & $6(20.0)$ & $24(80.0)$ & \\
\hline \multirow[t]{3}{*}{ Metastasis } & & & & & 0.015 & & & 0.028 & & & 0.005 \\
\hline & Metastatic & $28(66.6)$ & $6(21.4)$ & $24(85.7)$ & & $9(32.1)$ & $19(67.8)$ & & $7(25.0)$ & $21(75.0)$ & \\
\hline & $\begin{array}{c}\text { Non- } \\
\text { Metastatic }\end{array}$ & $14(33.3)$ & $4(28.5)$ & $8(57.1)$ & & $6(42.8)$ & $8(57.1)$ & & $5(35.7)$ & $9(64.2)$ & \\
\hline \multirow{3}{*}{$\begin{array}{l}\text { Chemotherapy } \\
\text { Status }\end{array}$} & & & & & 0.018 & & & 0.012 & & & 0.036 \\
\hline & $\begin{array}{l}\text { Treatment } \\
\text { naive }\end{array}$ & $8(19.0)$ & $5(62.5)$ & $3(37.5)$ & & $5(62.5)$ & $3(37.5)$ & & $6(75.0)$ & $2(25.0)$ & \\
\hline & Pre-treated & $34(80.9)$ & $5(14.7)$ & $29(85.2)$ & & $10(29.4)$ & $24(70.5)$ & & $6(17.6)$ & $28(82.4)$ & \\
\hline
\end{tabular}

4

5

6 


\section{Table 4 (on next page)}

Correlation of HIF-1 $\alpha$, MDR1, and LAPTM4B expression with clinico-pathological features of prostate cancer. The $\mathrm{N}$ shows the number of patients in each group. Where $\mathrm{p}$ value describes the significance and $p<0.05$ shows the significance of results. 
1 Table 4: Correlation of HIF-1 $\alpha$, MDR1, and LAPTM4B expression with clinico-pathological features of 2 prostate cancer. The $\mathrm{N}$ shows the number of patients in each group. Where $\mathrm{p}$ value describes the significance 3 and $\mathbf{p}<\mathbf{0 . 0 5}$ shows the significance of results.

\begin{tabular}{|c|c|c|c|c|c|c|c|c|c|c|c|}
\hline \multirow{2}{*}{\multicolumn{2}{|c|}{$\begin{array}{l}\text { Clinical-pathological } \\
\text { Characteristics }\end{array}$}} & \multirow{4}{*}{$\begin{array}{l}\text { ALL } \\
\text { N (\%) }\end{array}$} & \multirow{2}{*}{\multicolumn{2}{|c|}{$\begin{array}{c}\text { HIF-1a } \\
\text { expression }\end{array}$}} & & \multirow{2}{*}{\multicolumn{3}{|c|}{ MDR1 expression }} & \multirow{2}{*}{\multicolumn{3}{|c|}{ LAPTM4B expression }} \\
\hline & & & & & \multirow{3}{*}{$\begin{array}{c}p- \\
\text { value }\end{array}$} & & & & & & \\
\hline & & & \multirow{2}{*}{$\begin{array}{c}\text { Low } \\
\text { N (\%) }\end{array}$} & \multirow{2}{*}{$\begin{array}{c}\text { High } \\
\text { N (\%) }\end{array}$} & & Low & High & \multirow[t]{2}{*}{ p-value } & Low & High & \multirow[t]{2}{*}{$\begin{array}{c}p- \\
\text { value }\end{array}$} \\
\hline & & & & & & $\mathbf{N}(\%)$ & $\mathbf{N}(\%)$ & & N (\%) & $\mathbf{N}(\%)$ & \\
\hline \multirow[t]{3}{*}{ Stage } & & & & & 0.05 & & & 0.400 & & & 0.05 \\
\hline & I-II & $6(28.5)$ & $3(50.0)$ & $3(50.0)$ & & $5(83.3)$ & $1(20.0)$ & & $3(50.0)$ & $3(50.0)$ & \\
\hline & III-IV & $15(71.4)$ & $5(33.3)$ & $10(66.6)$ & & $4(26.6)$ & $11(73.3)$ & & $3(20.0)$ & $12(80.0)$ & \\
\hline \multirow[t]{3}{*}{ Metastasis } & & & & & 0.014 & & & $\mathbf{0 . 3 5 7}$ & & & 0.018 \\
\hline & Metastatic & $13(66.6)$ & $4(30.7)$ & $9(69.2)$ & & $6(46.1)$ & $7(53.8)$ & & $3(23.0)$ & $10(76.9)$ & \\
\hline & $\begin{array}{c}\text { Non- } \\
\text { Metastatic }\end{array}$ & $8(33.3)$ & $4(50.0)$ & $4(50.0)$ & & $3(37.5)$ & $5(62.5)$ & & $3(37.5)$ & $5(62.5)$ & \\
\hline \multirow[t]{3}{*}{$\begin{array}{c}\text { Chemotherapy } \\
\text { Status }\end{array}$} & & & & & 0.029 & & & 0.048 & & & 0.476 \\
\hline & $\begin{array}{c}\text { Treatment } \\
\text { naive }\end{array}$ & $7(19.0)$ & $4(57.1)$ & $3(42.8)$ & & $4(57.1)$ & $3(42.8)$ & & $1(14.2)$ & $6(85.7)$ & \\
\hline & Pre-treated & $14(80.9)$ & $4(28.5)$ & $10(71.4)$ & & $5(35.7)$ & $9(64.2)$ & & $5(35.7)$ & $9(64.2)$ & \\
\hline
\end{tabular}

4

5

6 


\section{Table 5 (on next page)}

Correlation of HIF-1 $\alpha$, MDR1, and LAPTM4B expression with clinico-pathological features of colon cancer. The $\mathrm{N}$ shows the number of patients in each group. Where $\mathrm{p}$ value describes the significance and $p<0.05$ shows the significance of results. 


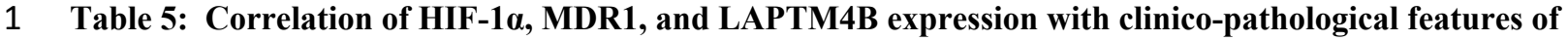
2 colon cancer. The $\mathbf{N}$ shows the number of patients in each group. Where $p$ value describes the significance 3 and $\mathbf{p}<\mathbf{0 . 0 5}$ shows the significance of results.

\begin{tabular}{|c|c|c|c|c|c|c|c|c|c|c|c|}
\hline \multirow{2}{*}{\multicolumn{2}{|c|}{$\begin{array}{l}\text { Clinical-pathological } \\
\text { Characteristics }\end{array}$}} & \multirow{3}{*}{$\begin{array}{c}\text { ALL } \\
\text { N (\%) }\end{array}$} & \multicolumn{3}{|c|}{ HIF-1 $\alpha$ expression } & \multicolumn{3}{|c|}{ MDR1 expression } & \multicolumn{3}{|c|}{ LAPTM4B expression } \\
\hline & & & \multirow{2}{*}{$\begin{array}{c}\text { Low } \\
\text { N (\%) }\end{array}$} & \multirow{2}{*}{$\begin{array}{c}\text { High } \\
\text { N (\%) }\end{array}$} & \multirow{2}{*}{$\begin{array}{c}p- \\
\text { value }\end{array}$} & \multirow{2}{*}{$\begin{array}{c}\text { Low } \\
\text { N (\%) }\end{array}$} & High & \multirow{2}{*}{$\begin{array}{c}p \text { - } \\
\text { value }\end{array}$} & \multirow{2}{*}{$\begin{array}{l}\text { Low } \\
\text { N (\%) } \\
\end{array}$} & High & \multirow{2}{*}{$\begin{array}{c}p- \\
\text { value }\end{array}$} \\
\hline & & & & & & & $\mathbf{N}(\%)$ & & & $\mathbf{N}(\%)$ & \\
\hline \multirow[t]{3}{*}{ Age } & & & & & 0.382 & & & 0.318 & & & 0.500 \\
\hline & $<\mathbf{5 0}$ & $20(62.5)$ & $9(45.0)$ & $11(55.0)$ & & $10(50.0)$ & $10(50.0)$ & & $11(55.0)$ & $9(45.0)$ & \\
\hline & $>\mathbf{5 0}$ & $12(37.5)$ & $3(25.0)$ & $9(75.0)$ & & $5(41.6)$ & $7(58.3)$ & & $6(50.0)$ & $6(50.0)$ & \\
\hline \multirow[t]{3}{*}{ Stage } & & & & & 0.016 & & & 0.005 & & & 0.007 \\
\hline & I-II & $13(40.6)$ & $7(53.8)$ & $4(30.7)$ & & $7(53.8)$ & $6(46.1)$ & & $9(69.2)$ & $4(30.8)$ & \\
\hline & III-IV & $19(59.3)$ & $5(26.3)$ & $16(84.2)$ & & $8(42.1)$ & $11(57.8)$ & & $8(42.1)$ & $11(57.8)$ & \\
\hline \multirow[t]{3}{*}{ Metastasis } & & & & & 0.045 & & & 0.024 & & & 0.055 \\
\hline & Metastatic & 21(65.6) & $7(33.3)$ & $18(85.7)$ & & $8(38.0)$ & $13(61.9)$ & & $8(38.0)$ & $11(52.4)$ & \\
\hline & $\begin{array}{c}\text { Non- } \\
\text { Metastatic }\end{array}$ & $11(34.3)$ & $5(45.45)$ & $2(18.2)$ & & $7(63.6)$ & $4(36.3)$ & & $9(81.8)$ & $4(36.4)$ & \\
\hline \multirow{3}{*}{$\begin{array}{c}\text { Chemotherapy } \\
\text { Status }\end{array}$} & & & & & 0.001 & & & 0.049 & & & 0.007 \\
\hline & $\begin{array}{c}\text { Treatment } \\
\text { naive }\end{array}$ & 13(40.6) & $6(46.1)$ & $7(53.8)$ & & $9(69.2)$ & $4(30.7)$ & & $9(69.2)$ & $4(30.7)$ & \\
\hline & Pre-treated & 19(59.3) & $6(31.5)$ & $15(78.9)$ & & $6(31.6)$ & $13(68.4)$ & & $8(42.1)$ & $11(57.8)$ & \\
\hline
\end{tabular}


Table 6 (on next page)

Association analysis between HIF-1 $\alpha$, MDR1 and LAPTM4B expression in breast cancer blood specimens. The number of patients having high expression of all the three genes are highlighted in grey. 
1 Table 6: Association analysis between HIF-1 $\alpha$, MDR1 and LAPTM4B expression in breast 2 cancer blood specimens. The number of patients having high expression of all the three genes are 3 highlighted in grey.

\begin{tabular}{|c|c|c|c|c|c|}
\hline & & \multicolumn{2}{|l|}{$\begin{array}{l}\text { MDR1 } \\
\text { (No. of cases) }\end{array}$} & \multicolumn{2}{|l|}{$\begin{array}{l}\text { LAPTM4B } \\
\text { (No. of cases) }\end{array}$} \\
\hline & & $\begin{array}{l}\text { High } \\
\text { Expression }\end{array}$ & $\begin{array}{l}\text { Low } \\
\text { expression }\end{array}$ & $\begin{array}{l}\text { High } \\
\text { Expression }\end{array}$ & $\begin{array}{l}\text { Low } \\
\text { expression }\end{array}$ \\
\hline \multirow{2}{*}{$\begin{array}{l}\text { HIF-1 } \alpha \\
\text { (No. of } \\
\text { cases) }\end{array}$} & $\begin{array}{l}\text { High } \\
\text { Expression }\end{array}$ & 51 & 0 & 51 & 0 \\
\hline & $\begin{array}{l}\text { Low } \\
\text { expression }\end{array}$ & 3 & 18 & 4 & 17 \\
\hline \multirow{2}{*}{$\begin{array}{l}\text { MDR1 } \\
\text { (No. of } \\
\text { cases) }\end{array}$} & $\begin{array}{l}\text { High } \\
\text { Expression }\end{array}$ & & & 54 & 1 \\
\hline & $\begin{array}{l}\text { Low } \\
\text { expression }\end{array}$ & & & 0 & 17 \\
\hline
\end{tabular}

$4 \quad R=0.900, P<0.000$ 


\section{Table 7 (on next page)}

Association analysis between HIF-1 $\alpha$, MDR1 and LAPTM4B expression in ovarian cancer blood specimens. The number of patients having high expression of all the three genes are highlighted in grey. 
1 Table 7: Association analysis between HIF-1 $\alpha$, MDR1 and LAPTM4B expression in ovarian 2 cancer blood specimens. The number of patients having high expression of all the three genes are 3 highlighted in grey.

\begin{tabular}{|c|c|c|c|c|c|}
\hline & & \multicolumn{2}{|l|}{$\begin{array}{l}\text { MDR1 } \\
\text { (No. of cases) }\end{array}$} & \multicolumn{2}{|l|}{$\begin{array}{l}\text { LAPTM4B } \\
\text { (No. of cases) }\end{array}$} \\
\hline & & $\begin{array}{l}\text { High } \\
\text { Expression }\end{array}$ & $\begin{array}{l}\text { Low } \\
\text { expression }\end{array}$ & $\begin{array}{l}\text { High } \\
\text { Expression }\end{array}$ & $\begin{array}{l}\text { Low } \\
\text { expression }\end{array}$ \\
\hline \multirow{2}{*}{ 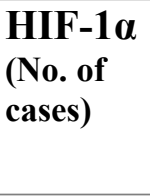 } & $\begin{array}{l}\text { High } \\
\text { Expression }\end{array}$ & 27 & 5 & 30 & 2 \\
\hline & $\begin{array}{l}\text { Low } \\
\text { expression }\end{array}$ & 0 & 10 & 0 & 10 \\
\hline \multirow{2}{*}{$\begin{array}{l}\text { MDR1 } \\
\text { (No. of } \\
\text { cases) }\end{array}$} & $\begin{array}{l}\text { High } \\
\text { Expression }\end{array}$ & & & 27 & 3 \\
\hline & $\begin{array}{l}\text { Low } \\
\text { expression }\end{array}$ & & & 0 & 12 \\
\hline
\end{tabular}

5

6 


\section{Table 8 (on next page)}

Association analysis between HIF-1 $\alpha$, MDR1 and LAPTM4B expression in prostate cancer blood specimens. The number of patients having high expression of all the three genes are highlighted in grey. 
1 Table 8: Association analysis between HIF-1 $\alpha$, MDR1 and LAPTM4B expression in prostate 2 cancer blood specimens. The number of patients having high expression of all the three genes are 3 highlighted in grey.

\begin{tabular}{|c|c|c|c|c|c|}
\hline & & \multicolumn{2}{|l|}{$\begin{array}{l}\text { MDR1 } \\
\text { (No. of cases) }\end{array}$} & \multicolumn{2}{|l|}{$\begin{array}{l}\text { LAPTM4B } \\
\text { (No. of cases) }\end{array}$} \\
\hline & & $\begin{array}{l}\text { High } \\
\text { Expression }\end{array}$ & $\begin{array}{l}\text { Low } \\
\text { expression }\end{array}$ & $\begin{array}{l}\text { High } \\
\text { Expression }\end{array}$ & $\begin{array}{l}\text { Low } \\
\text { expression }\end{array}$ \\
\hline \multirow{2}{*}{$\begin{array}{l}\text { HIF-1 } \alpha \\
\text { (No. of } \\
\text { cases) }\end{array}$} & $\begin{array}{l}\text { High } \\
\text { Expression }\end{array}$ & 12 & 1 & 13 & 0 \\
\hline & $\begin{array}{l}\text { Low } \\
\text { expression }\end{array}$ & 0 & 8 & 2 & 6 \\
\hline \multirow{2}{*}{$\begin{array}{l}\text { MDR1 } \\
\text { (No. of } \\
\text { cases) }\end{array}$} & $\begin{array}{l}\text { High } \\
\text { Expression }\end{array}$ & & & 12 & 3 \\
\hline & $\begin{array}{l}\text { Low } \\
\text { expression }\end{array}$ & & & 0 & 6 \\
\hline
\end{tabular}




\section{Table 9 (on next page)}

Association analysis between HIF-1 $\alpha$, MDR1 and LAPTM4B expression in colon cancer blood specimens. The number of patients having high expression of all the three genes are highlighted in grey. 
1 Table 9: Association analysis between HIF-1 $\alpha$, MDR1 and LAPTM4B expression in colon 2 cancer blood specimens. The number of patients having high expression of all the three genes are 3 highlighted in grey.

\begin{tabular}{|c|c|c|c|c|c|}
\hline & & \multicolumn{2}{|l|}{$\begin{array}{l}\text { MDR1 } \\
\text { (No. of cases) }\end{array}$} & \multicolumn{2}{|l|}{$\begin{array}{l}\text { LAPTM4B } \\
\text { (No. of cases) }\end{array}$} \\
\hline & & $\begin{array}{l}\text { High } \\
\text { Expression }\end{array}$ & $\begin{array}{l}\text { Low } \\
\text { expression }\end{array}$ & $\begin{array}{l}\text { High } \\
\text { Expression }\end{array}$ & $\begin{array}{l}\text { Low } \\
\text { expression }\end{array}$ \\
\hline \multirow{2}{*}{$\begin{array}{l}\text { HIF-1 } \alpha \\
\text { (No. of } \\
\text { cases) }\end{array}$} & $\begin{array}{l}\text { High } \\
\text { Expression }\end{array}$ & 12 & 1 & 15 & 5 \\
\hline & $\begin{array}{l}\text { Low } \\
\text { expression }\end{array}$ & 0 & 8 & 0 & 12 \\
\hline \multirow{2}{*}{$\begin{array}{l}\text { MDR1 } \\
\text { (No. of } \\
\text { cases) }\end{array}$} & $\begin{array}{l}\text { High } \\
\text { Expression }\end{array}$ & & & 15 & 0 \\
\hline & $\begin{array}{l}\text { Low } \\
\text { expression }\end{array}$ & & & 2 & 15 \\
\hline
\end{tabular}

$4 \quad R=0.825, P<0.000$

5

6

7

8

9 


\section{Figure 1}

Expression of HIF-1 $\alpha$, MDR1 and LAPTM4B.

Expression of HIF-1 $\alpha$ in (a) Breast cancer $(n=72)$ and ovarian cancer $(n=42)$ patients compared to healthy controls ( $n=50)$; (b) Prostate cancer $(n=21)$ and Colon cancer $(n=32)$ compared to healthy controls ( $n=25)$. Expression of MDR1 in (c) Breast cancer $(n=72)$ and ovarian cancer ( $n=42)$ patients compared to healthy controls $(n=50)$; (d) Prostate cancer $(n=21)$ and Colon cancer $(n=32)$ compared to healthy controls $(n=25)$. Expression of LAPTM4B in (e) Breast cancer $(n=72)$ and ovarian cancer $(n=42)$ patients compared to healthy controls ( $n=50)$; (f) Prostate cancer $(n=21)$ and Colon cancer $(n=32)$ compared to healthy controls $(n=25)$. There is increased HIF-1 $\alpha$, MDR1 and LAPTM4B expression in cancer patients compared to healthy controls. Representative data were presented as mean \pm SEM of triplicate experiments. Statistical significance was measured by student's t-test $\left({ }^{* *} p<\right.$ 0.001 ). 

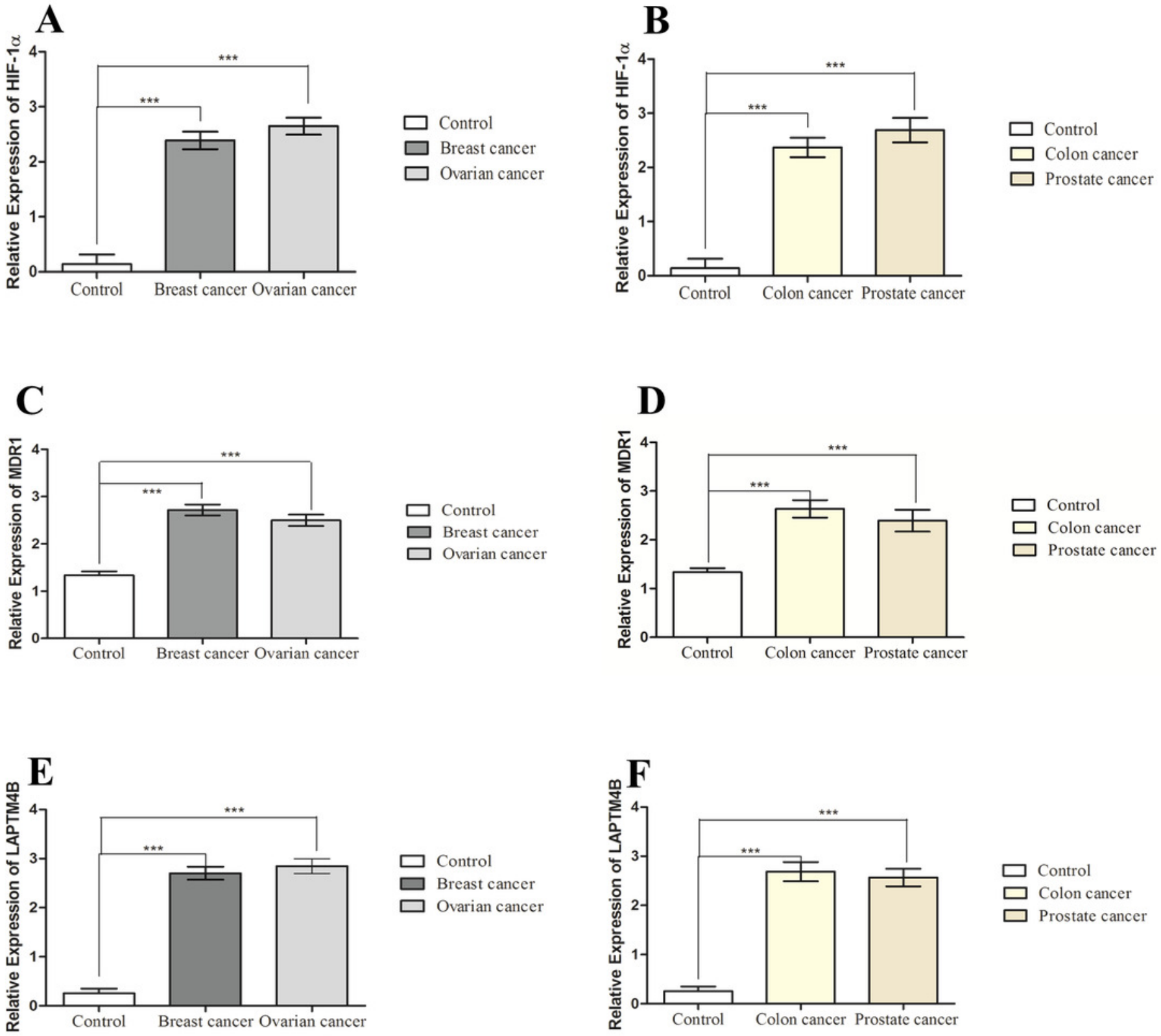


\section{Figure 2}

Correlation of HIF-1 $\alpha$, MDR1 and LAPTM4B expression with clinical features of breast cancer.

Correlation of HIF-1 $\alpha$ expression with (a) tumor stage, (b) metastasis, and (c) chemotherapy treatment in breast cancer patients. Correlation of MDR1 expression with (d) tumor stage, (e) metastasis, and (f) chemotherapy treatment in breast cancer patients. Correlation of LAPTM4B overexpression with $(\mathrm{g})$ tumor stage, (h) metastasis, and (i) chemotherapy treatment in breast cancer patients. There is an elevated expression of HIF-1 $\alpha$, MDR1 and LAPTM4B in metastatic, higher tumor stage and pre-treated group compared to nonmetastatic, lower tumor stage and treatment naïve group. Representative data were presented as mean \pm SEM of triplicate experiments. Statistical significance was measured by Fisher's Exact test $\left({ }^{*} p<0.05 ;{ }^{* *} p \leq 0.005 ;{ }^{* * *} p<0.001\right)$.
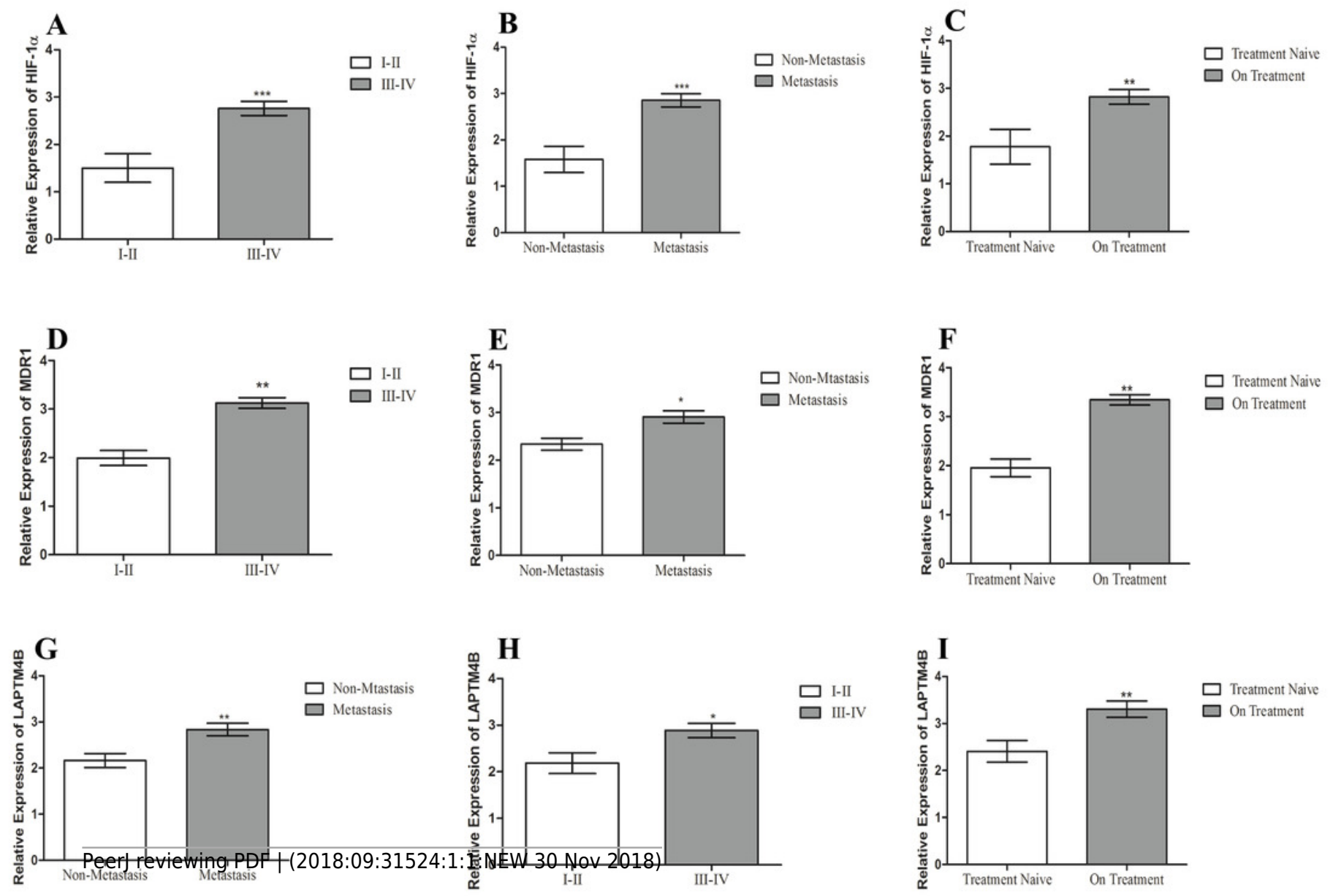


\section{Figure 3}

Correlation of HIF-1 $\alpha$, MDR1 and LAPTM4B expression with clinical features of ovarian cancer.

Correlation of HIF-1 $\alpha$ expression with (a) tumor stage, (b) metastasis, and (c) chemotherapy treatment in ovarian cancer patients. Correlation of MDR1 expression with (d) tumor stage, (e) metastasis, and (f) chemotherapy treatment in ovarian cancer patients. Correlation of LAPTM4B overexpression with $(\mathrm{g})$ tumor stage, $(\mathrm{h})$ metastasis, and (i) chemotherapy treatment in ovarian cancer patients. The high expression of HIF-1 $\alpha$, MDR1 and LAPTM4B is observed in metastatic, high tumor stage and pre-treated group compared to non-metastatic, lower tumor stage and treatment naïve group. Representative data were presented as mean \pm SEM of triplicate experiments. Statistical significance was measured by Fisher's Exact test $(* p \leq 0.05)$.
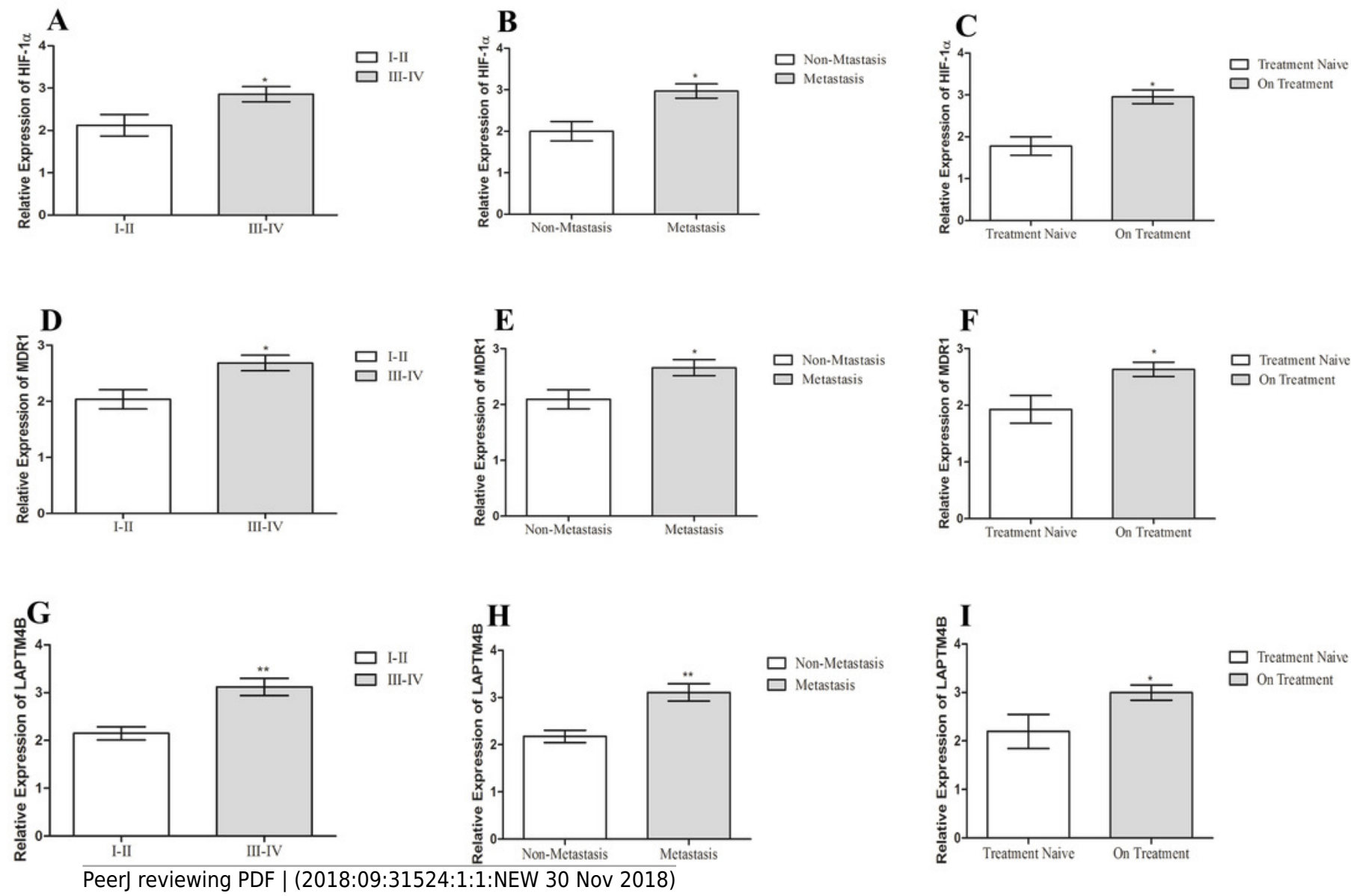


\section{Figure 4}

Correlation of HIF-1 $\alpha$, MDR1 and LAPTM4B expression with clinical features of prostate cancer.

Correlation of HIF-1 $\alpha$ expression with (a) tumor stage, (b) metastasis, and (c) chemotherapy treatment in prostate cancer patients. Correlation of MDR1 expression with (d) tumor stage, (e) metastasis, and (f) chemotherapy treatment in prostate cancer patients. Correlation of LAPTM4B overexpression with $(\mathrm{g})$ tumor stage, (h) metastasis, and (i) chemotherapy treatment in prostate cancer patients. The high expression of HIF-1 $\alpha$ and LAPTM4B is observed in metastatic and higher tumor stage group compared to non-metastatic and lower tumor stage group. No correlation is observed for MDR1 with clinical features. There is almost similar expression of MDR1 in Representative data were presented as mean \pm SEM of triplicate experiments. Statistical significance was measured by Fisher's Exact test $(* p \leq 0.05)$.
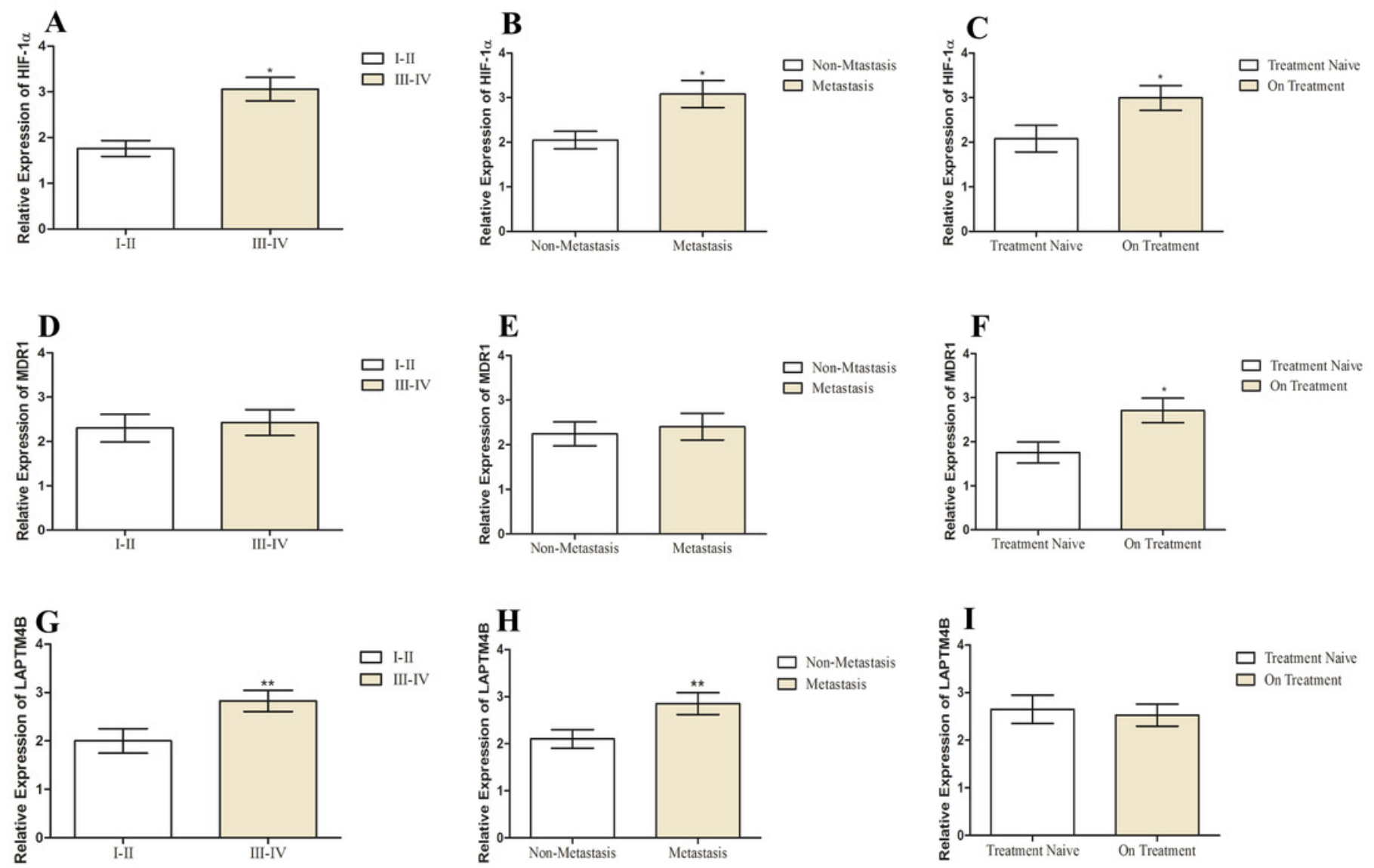


\section{Figure 5}

Correlation of HIF-1 $\alpha$, MDR1 and LAPTM4B expression with clinical features of colon cancer.

Correlation of HIF-1 $\alpha$ expression with (a) tumor stage, (b) metastasis, and (c) chemotherapy treatment in colon cancer patients. Correlation of MDR1 expression with (d) tumor stage, (e) metastasis, and (f) chemotherapy treatment in colon cancer patients. Correlation of LAPTM4B overexpression with $(\mathrm{g})$ tumor stage, $(\mathrm{h})$ metastasis, and (i) chemotherapy treatment in colon cancer patients. There is elevated expression of HIF-1 $\alpha$, MDR1 and LAPTM4B observed in metastatic, higher tumor stage and treatment naïve group compared to non-metastatic, lower tumor stage and pre-treated group. Representative data were presented as mean \pm SEM of triplicate experiments. Statistical significance was measured by Fisher's Exact test $(* \mathrm{p} \leq 0.05 ; * * \mathrm{p} \leq 0.005)$.
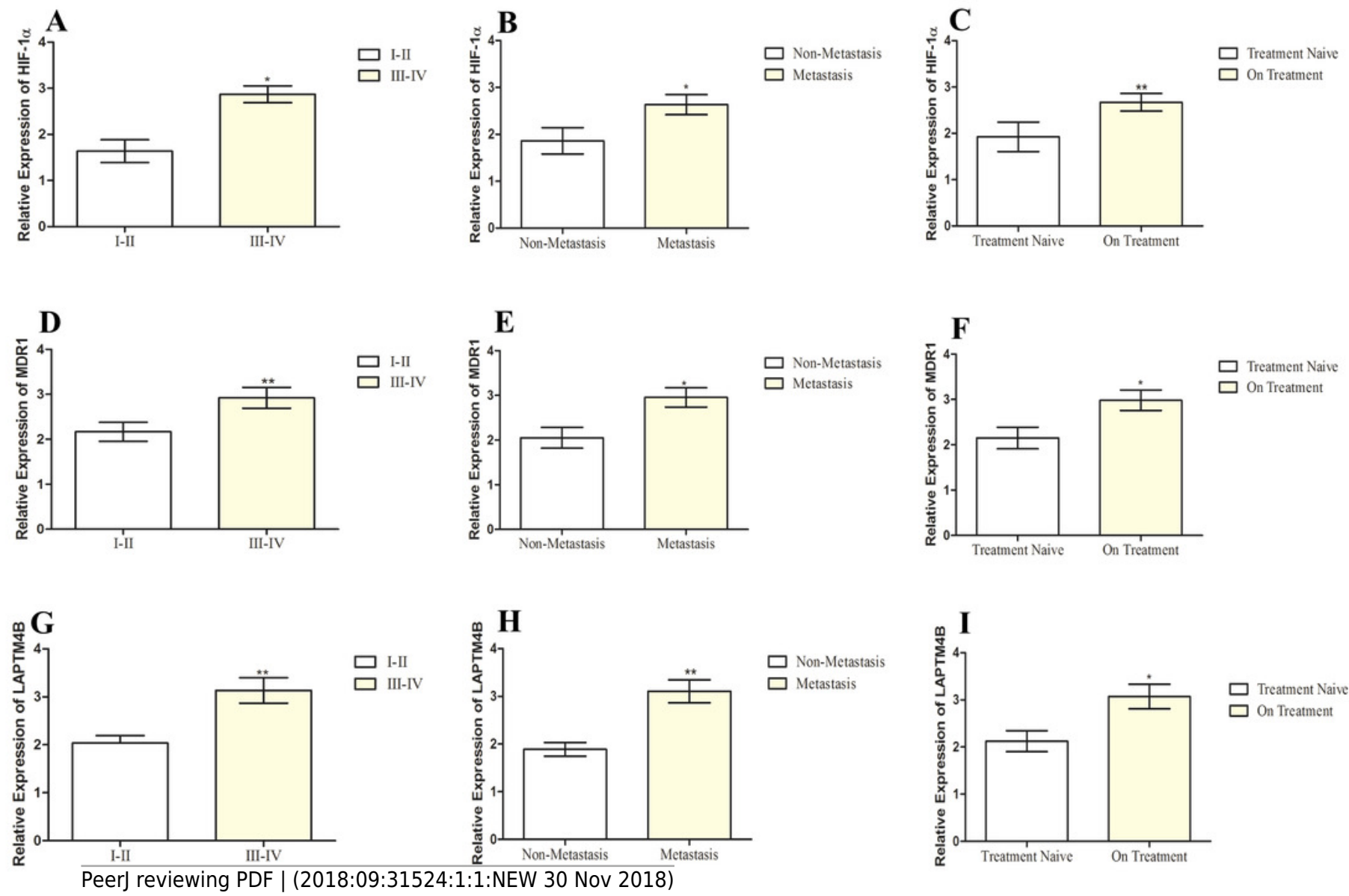